Pre-print copy of Upson, M.A., Burgess, P.J., Morison J.I.L. (2016). Soil carbon changes after establishing woodland and agroforestry trees in a grazed pasture. Geoderma 283: 10-20.

\title{
Soil carbon changes after establishing woodland and agroforestry trees in a grazed pasture
}

\author{
M.A. Upson ${ }^{a}$, P.J. Burgess ${ }^{a,}{ }^{*}$, J.I.L. Morison ${ }^{b}$ \\ ${ }^{a}$ School of Water, Energy and Environment, Cranfield University, Cranfield, Bedfordshire, \\ MK43 OAL, UK \\ ${ }^{b}$ Forest Research, Alice Holt Lodge, Farnham, Surrey, GU10 4LH, UK \\ *Corresponding author: P.Burgess@cranfield.ac.uk
}

\begin{abstract}
This study determined the effect of two tree planting methods (woodland and a silvopastoral agroforestry system) on the soil bulk density and organic carbon content of a grassland site in lowland England. Soil organic carbon was measured in pasture, silvopastoral tree, and woodland treatments at six depths representative of 0-150 cm. Fourteen years after tree planting, the organic carbon content in the surface soil layer (0-10

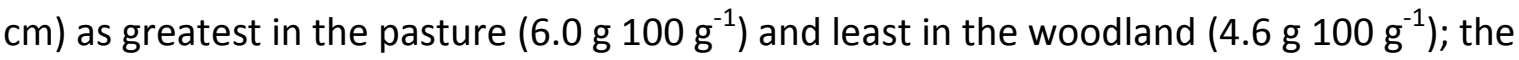

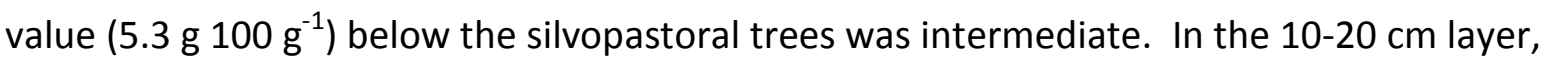
the organic carbon content in the woodland was $13 \%$ lower than the pasture. No treatment effects on soil carbon were detected below $20 \mathrm{~cm}$. Possible reasons for the decline in surface soil carbon include a decline in grass cover and reduced soil water content. Measurements of above ground carbon storage by the trees indicated that tree planting increased overall carbon storage, with the silvopastoral system predicted to achieve a higher level of carbon storage than equivalent areas of separate woodland and pasture. A power analysis indicates that a prohibitively large number of replicates is needed to ensure a lower than $20 \%$ risk of falsely concluding no treatment differences at individual depth increments below $10 \mathrm{~cm}$ and cumulative depths extending below $40 \mathrm{~cm}$.
\end{abstract}

Keywords: silvopasture, grassland, carbon sequestration, forest, carbon time

\section{Introduction}

Agroforestry is the practice of deliberately integrating woody vegetation (trees or shrubs) with crop and/or animal systems to benefit from the resulting ecological and economic interactions. It can offer benefits in terms of improving animal welfare (Broom et al., 2013), reducing runoff (Udawatta et al., 2011) and increasing land productivity (Graves et al., 2007). It is also widely cited as having great potential for the sequestration of atmospheric 
carbon (IPCC, 2000; Montagnini and Nair, 2004; Jose, 2009; Mosquera-Losada et al., 2011; UNEP 2011). However whilst planting trees on grassland will undoubtedly lead to an accumulation of above ground carbon, it may not increase the level of soil organic carbon (SOC).

Existing large meta-analyses have shown that tree planting on pasture, at least in the short term, can lead to declines in soil organic carbon (Post and Kwon, 2000; Paul and Polglase, 2002; Guo and Gifford, 2002; Laganiere et al., 2010; Shi et al., 2013). Guo and Gifford (2002) and Kirschbaum et al. (2008) suggest that such losses tend to be exacerbated in areas of high rainfall. By contrast, other authors suggest that the losses may be restricted to the most labile 'light fraction' or particulate organic matter (POM), and stocks may recover over a long enough time span (Paul et al., 2003; Huang et al., 2011; Hoogmoed et al., 2012).

Very few studies consider the effect on SOC of silvopastoral systems where the trees are planted to allow continued grazing on all or part of the land. Unlike woodland systems, silvopastoral trees allow lateral access of solar radiation and grass cover can be maintained below the trees. Since a silvopastoral system can maintain a combination of tree and grass roots and root turnover is a key pathway for carbon to enter the soil, the carbon inputs in a silvopastoral system may be larger than monoculture pasture or woodland. In addition root carbon is known to be more recalcitrant than shoot carbon (Jackson et al., 1997; Rasse et al., 2005,), and the increased diversity of species may increase soil stocks (Stockmann et al., 2013).

One of the difficulties in attempting to assess changes in SOC is that the magnitude of any change tends to be very small in relation to the variation (Hungate et al., 1995; Kravchenko and Robertson, 2011). This high coefficient of variation (CV) in turn results in low experimental power, i.e. a poor ability the separate any signal from the noise. Shi et al. (2013), Upson and Burgess (2013) and Harper and Tibbett (2013) have all highlighted the importance of sampling sufficiently deeply for SOC. However increasing the depth of sampling also lowers the experimental power as the CV tends to be greater with increased sampling depth. For this reason, post-hoc power analyses are useful for determining if the experiment can be expected to result in type II errors, i.e. the incorrect conclusion that there are no differences in SOC between treatments.

During the 1990s, a number of agroforestry experiments and demonstration sites were established on agricultural land in the UK (Burgess et al., 2000, 2005; Sibbald et al., 2001). Hence by 2012, it was considered that it may be possible to detect changes in SOC at such sites. The aims of this study are threefold: to assess the change in SOC following conversion of pasture to silvopasture and farm woodland at a lowland site in the east of England; to determine the relationship between SOC, soil bulk density $\left(\rho_{b}\right)$, fine root mass density (FRMD) and mean soil moisture content $(\theta)$; and to estimate the minimum number of 
samples required to ensure sufficient experimental power whilst sampling SOC over a 0-150 $\mathrm{cm}$ profile.

\section{Material and methods}

\subsection{Site description}

The 14 ha experiment site at Clapham Park $\left(52^{\circ} 9^{\prime} 36^{\prime \prime} \mathrm{N}, 02^{\circ} 8^{\prime} 27^{\prime \prime} \mathrm{W}\right)$, near Bedford in England, declines from about $62 \mathrm{~m}$ above sea level in the west to $50 \mathrm{~m}$ in the east. The soil belongs to the Evesham soil series of 'slowly permeable calcareous clays, and fine loamy over clayey soils' (NSRI, 2012). It is referred to as a 'calcaric stagnic vertic cambisol' in the World Reference Base classification (Cranfield University, 2014). The mean texture of the soil was found to be $25.8 \pm 1.4 \%$ sand $(0.063-2 \mathrm{~mm}), 31.8 \pm 1.1 \%$ silt $(0.002-0.063 \mathrm{~mm})$, and $42.4 \pm 1.3 \%$ clay $(<0.002 \mathrm{~mm})$.

Mean daily air temperature (derived from the Bedford and Woburn MIDAS stations) for the years $2003-2013$ was $10.2^{\circ} \mathrm{C}$. Annual precipitation for the years 2002-2013 varied between $430 \mathrm{~mm}$ in 2005 and $921 \mathrm{~mm}$ in 2007 (mean: $652 \mathrm{~mm}$ ).

Historical mapping of the Clapham Park Estate (Page, 1912; Landmark Information Group, 2004 ) indicates that from 1880 to 1998, the experimental field had a parkland landscape with widely-spaced individual trees and a small number of tree groups. In February 1998, as part of the "Bedfordshire Farm Woodland Demonstration Project" (Burgess et al., 2000), trees were planted on the site in two types of system. The southern part of the field was fenced and planted as woodland with a mixture of broadleaf tree species at $2.5 \mathrm{~m}$ spacing (Table 1). One of the key species planted was ash (Fraxinus excelsior). Since 1998, the woodland has received minimal management except the mowing of pathways to promote local access.

The remainder of the site was planted as a silvopastoral system comprising 34 discrete blocks of trees; 30 consisting of 16 trees, with four large blocks of 75 trees (Table 1, Figure 1). The silvopastoral area has continued to be leased by the tenant farmer for grazing a suckler-beef herd typically at a stocking rate of 2.5 cows per hectare. Cattle graze most of the season apart from a 3-4 week period before mowing for hay or silage crops in June and September. The pasture is fertilised at a rate of $100 \mathrm{~kg} \mathrm{~N} \mathrm{ha}^{-1}$. In 2012, 14 years after tree planting, the diameter at breast height $\left(D_{b h}\right)$ of the ash trees in the silvopastoral blocks (121 $\mathrm{mm}$ ) was larger $(\mathrm{p}=<0.001)$ than the diameter $(92 \mathrm{~mm})$ of the ash trees in the woodland. In the field next to the experimental site is a grazed area with mature ash trees, called Helen's Wood, that appears to have been a wooded area in the 1880s (Landmark Information Group, 2004). This mature silvopastoral system is also used by the tenant farming for cattle grazing. 
Table 1. Description of the silvopastoral and woodland system planted at Clapham in February 1998.

\begin{tabular}{|c|c|c|}
\hline System and area & Arrangement of trees & Species composition \\
\hline $\begin{array}{l}\text { Block silvopasture system } \\
\text { comprising } 0.31 \text { ha of } \\
\text { silvopastoral trees and } 7.03 \\
\text { ha of pasture ( } 7.34 \text { ha in } \\
\text { total) }\end{array}$ & $\begin{array}{l}4 \text { fenced groups of } 75 \text { trees at } 2 \\
m \times 2 \mathrm{~m} \text { spacing ( } 0.12 \text { ha) } \\
30 \text { fenced groups of } 16 \text { trees at } 2 \\
m \times 2 \mathrm{~m} \text { spacing ( } 0.19 \text { ha) }\end{array}$ & $\begin{array}{l}40 \% \text { oak, } 30 \% \text { ash, } 10 \% \\
\text { hornbeam, } 10 \% \text { small- } \\
\text { leaved lime, } 10 \% \text { field } \\
\text { maple }\end{array}$ \\
\hline $\begin{array}{l}\text { Mixed broadleaf woodland } \\
\text { covering } 6.85 \text { ha }\end{array}$ & $\begin{array}{l}\text { Fenced; principally at } 2.5 \times 2.5 \mathrm{~m} \\
\text { spacing }\left(1600 \text { trees } \mathrm{ha}^{-1}\right) .\end{array}$ & $\begin{array}{l}30 \% \text { ash, } 10 \% \text { oak, } 10 \% \\
\text { wild cherry, } 10 \% \text { small- } \\
\text { leaved lime , } 20 \% \text { 'shrub } \\
\text { mixture', } 20 \% \text { open } \\
\text { ground to form } \\
\text { footpaths and glades. }\end{array}$ \\
\hline
\end{tabular}

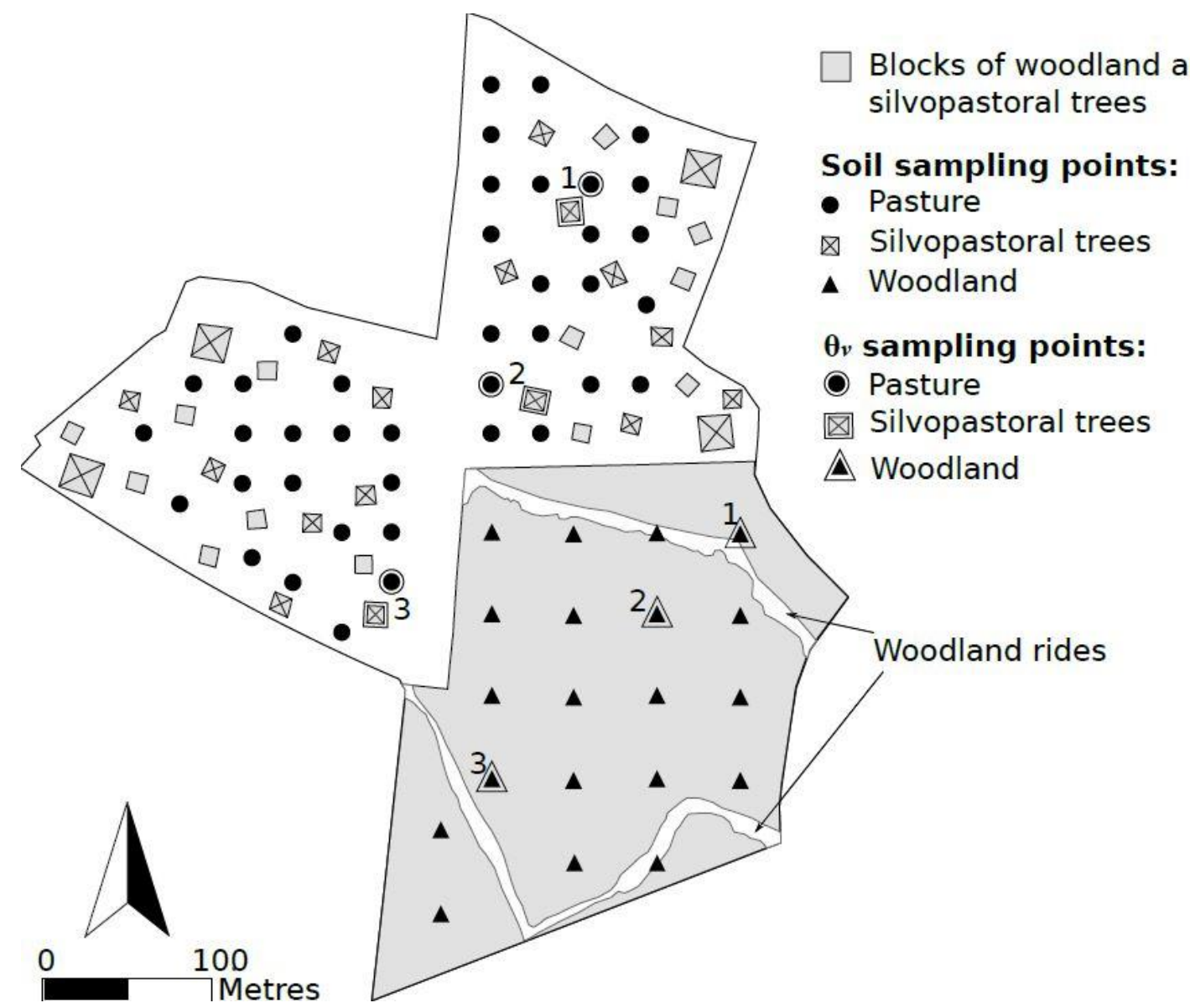

Figure 1. Schematic map of the Clapham Park field site. All hollow squares represent silvopasture tree blocks. Some of these were sampled (denoted by cross). Soil sampling points in the pasture and woodland were arranged on $30 \mathrm{~m} \times 30 \mathrm{~m}$ and $50 \mathrm{~m} \times 50 \mathrm{~m}$ grids respectively (the former included a buffer to avoid taking a sample too closely to trees). If soil moisture $\left(\theta_{v}\right)$ measurements were taken in a sampling location, these points have been marked by a solid black line surrounding the appropriate symbol, and are numbered. 


\subsection{Soil organic carbon content}

In 2012, fourteen years after tree planting, a series of measurements were taken to determine the effect of the tree planting on soil properties. Soil samples were obtained from the woodland (20 locations), the silvopastoral trees (20 locations) and the pasture (40 locations), with sampling points arranged on a $50 \mathrm{~m} \times 50 \mathrm{~m}$ and a $30 \mathrm{~m} \times 30 \mathrm{~m}$ grid in the woodland and pasture respectively (Figure 1). The 20 sampling points below the silvopastoral trees were selected at random from the 34 tree blocks. All sampling locations in the pasture were taken at least $10 \mathrm{~m}$ from any tree or any hedgerow to minimize interference with carbon measurements.

To determine the effect on soil organic carbon content, soil cores (of approximately $5 \mathrm{~cm}$ length) centred upon depths of 5, 15, 30, 50, 83 and $120 \mathrm{~cm}$ were extracted with a hand corer at each of the 80 locations ( 480 samples) between July and October 2012. These samples were assumed to be representative of $0-10,10-20,20-40,40-60,60-105$, and 105-150 cm. Surface leaf litter was cleared prior to sampling. The soil samples were dried at $40^{\circ} \mathrm{C}$, passed through a $2 \mathrm{~mm}$ sieve, and then fine ground. The organic carbon content $\mathrm{g}$ $100 \mathrm{~g}^{-1}$ ) was then measured by dry combustion using a Vario EL III Elemental Analyser (Elementar Analysensysteme $\mathrm{GmbH}$, Hanau, Germany. http://uk.elementar.de). Because some deep soil samples (>100 cm) contained large amounts of inorganic carbonates, each sample was treated with dilute $\mathrm{HCl}$ until no reaction with carbonates was observed. Despite this, some of the organic carbon values lay beyond three times the median absolute deviation (Leys et al., 2013); these values were considered to be caused by measurement error and were replaced with the median of the remaining values in that treatment $x$ depth group. This resulted in the substitution of 24 values, 20 of which were at depths greater than $40 \mathrm{~cm}$.

\subsection{Soil bulk density}

To determine soil bulk density, three replicate samples were taken at the apices of a triangle with each organic carbon sample at its centroid, $30 \mathrm{~cm}$ away from each of the corners at each of four depths of $5,15,30$, and $50 \mathrm{~cm}$ (480 samples). These samples were extracted vertically with a hand corer of internal diameter $4.51 \mathrm{~cm}$, and the resulting core cut to a length of $5-10 \mathrm{~cm}$ (dependent on the intactness of the core - see appendix). The increments between each sampling depth were removed sequentially to minimize compaction by the auger. The samples were then dried in a laboratory to a constant mass and bulk density $\left(\mathrm{g} \mathrm{cm}^{-3}\right)$ calculated by dividing sample mass by core volume. The three replicates were averaged to give a single value for each sampling point at each depth. No correction was made for the presence of stones and rock fragments, which were infrequent. Since sampling below $50 \mathrm{~cm}$ was not feasible, we assumed that bulk density did not change below $50 \mathrm{~cm}$, this assumption was supported by Upson and Burgess (2013) who reported no change no difference in bulk density beneath $20 \mathrm{~cm}$ in another agroforestry site in Bedfordshire. 


\subsection{Soil organic carbon on equivalent soil mass basis}

Because of volume changes which occurred as a result of changes in the bulk density, we analysed SOC on an equivalent soil mass (ESM) basis (Ellert and Bettany, 1995), and

followed Bambrick et al. (2010) in assuming a reference soil bulk density $\left(\rho_{b}\right)$ of $1.0 \mathrm{~g} \mathrm{~cm}^{-3}$.

\subsection{Carbon fractionation}

Soil samples, used to determine the different types of soil carbon, were obtained by aggregating a fixed mass of soil from each sampling point within a treatment for the $0-10$ $\mathrm{cm}$ and $10-20 \mathrm{~cm}$ depth increments. Five samples from each aggregated treatment and depth pool were then separated into fractions using the Zimmermann et al. (2007) method. The five fractions derived were dissolvable organic carbon (DOC), particulate organic matter (POM), chemically resistant soil organic carbon ( $\mathrm{rSOC}$ ), sand and stable aggregates ( $\mathrm{S}+\mathrm{A})$, and silt and clay fraction $(\mathrm{s}+\mathrm{c})$. The chemically resistant soil organic carbon $(\mathrm{s}+\mathrm{c}-\mathrm{rSOC})$ is derived from the value of $s+c$ minus $r S O C$.

\subsection{Fine root mass}

Fine root mass density (FRMD) was measured by releasing fine roots from the soil cores used to determine bulk density. To release the fine roots, the core was inserted into a 250 $\mathrm{cm}^{3}$ plastic bottle, filled with deionised water and placed inside an end-over-end agitator for at least $12 \mathrm{~h}$. The root material was then floated off from the bottle, and caught on a sieve with $710 \mu \mathrm{m}$ apertures. The clay and silt slurry was washed away, and root material dried at $105^{\circ} \mathrm{C}$ and then weighed. The fine root mass density $\left(\mathrm{mg} \mathrm{cm}^{-3}\right)$ was calculated as the mass of the fine roots divided by the core volume.

\subsection{Soil moisture content}

Soil moisture was measured at three points in each of the three treatments (nine access tubes; Figure 1) on a fortnightly basis between 23 October 2013 and 19 March 2014 using a 'Diviner 2000' capacitance probe (Sentek Sensor Technologies, 77 Magill Road, Stepney SA 5069, Australia. www.sentek.com.au). Readings were taken at $10 \mathrm{~cm}$ increments between $15 \mathrm{~cm}$ and $125 \mathrm{~cm}$, however one tube in both the woodland and silvopastoral treatments (Figure 1) extended to a reduced depth, due to difficulties in installing the tubes by hand. Volumetric moisture content $\left(\theta_{v}\right)$ was calculated using the calibration equation for a nearby clay soil given by Burgess et al. (2006).

\subsection{Statistical and power analyses}

Statistical analyses were completed using the statistical development environment: $R$, version 3.2.2 (R Development Core Team, 2015). Data handling was conducted with the package 'dplyr' (Wickham and Francois, 2015). Analysis of variance (ANOVA) was used to test for differences between groups, and model assumptions were checked using diagnostic plots. A random effect was included in the statistical models to take account of the 
proximity of the pasture and silvopastoral plots. A random effect for date was also included in the ANOVA of the water measurements with the capacitance probe to account for temporal pseudoreplication.

Transformations of the data were made where appropriate. Multiple comparisons between group means were made using the least significant test function, implemented in the package 'agricolae' (de Mendiburu, 2014), utilizing the Benjamini \& Hochberg correction to control the family-wise error rate (Benjamini and Hochberg, 1995).

For the power analyses, the 'power.t.test' function within the 'base' package of $\mathrm{R}$ was used to determine the statistical robustness of the cumulative SOC values from the woodland and pasture. The probability of incorrectly rejecting the null hypothesis $(\alpha)$ was set at 0.05 , and the probability of failing to reject a false null hypothesis $(\beta)$ was set at 0.2 , i.e. a $20 \%$ chance of wrongly concluding that there is no difference between treatments. Tests were run for six depth increments $(0-10,10-20,20-40,40-60,60-105$, and 105-150 cm) and each cumulative depth increment $(0-10,0-20,0-40,0-60,0-105$, and 0-150 cm). Since there were twice as many samples collected in the pasture as the woodland, 20 samples were chosen at random from the 40 pasture samples.

\section{Results}

\subsection{Soil bulk density and water content}

Overall the soil bulk density $\left(\rho_{b}\right)$ below the pasture $\left(1.19 \pm 0.01 \mathrm{~g} \mathrm{~cm}^{-3}\right)$ was less $(p<0.001)$ than that below the woodland $\left(1.23 \pm 0.02 \mathrm{~g} \mathrm{~cm}^{-3}\right)$ and the silvopastoral trees $(1.24 \pm 0.02 \mathrm{~g}$ $\mathrm{cm}^{-3}$ ) which were similar (Figure 2). In each treatment, the soil bulk density increased with depth, with each depth increment having a larger $(p<0.05)$ density than the increment above (Figure 3). There was no treatment $x$ depth interaction (Table 2). 


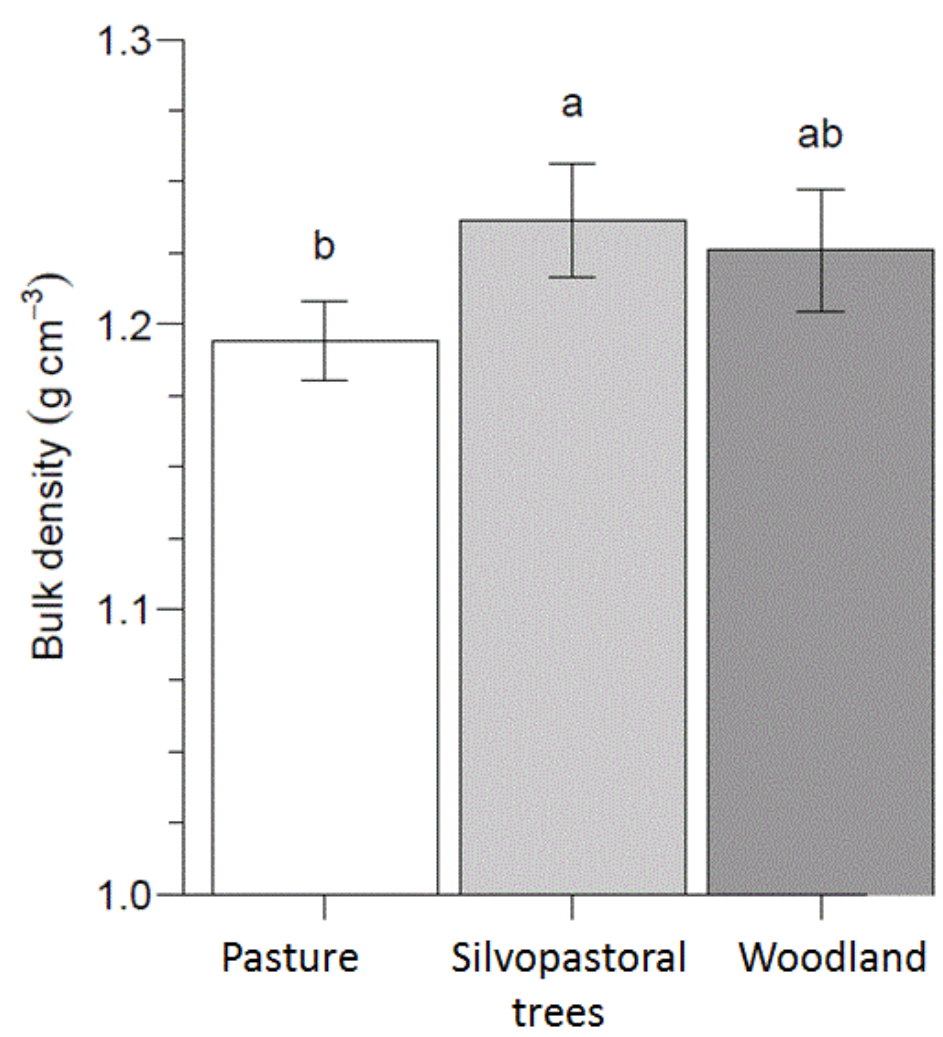

Figure 2. Soil bulk density $\left(\rho_{b}\right)$ for the pasture $(n=160)$, silvopasture tree $(n=80)$, and woodland $(n=$ 80) treatments at Clapham Park. Bars represent unweighted means of all depth increments: 0-10 $\mathrm{cm}, 10-20 \mathrm{~cm}, 20-40 \mathrm{~cm}$, and $40-60 \mathrm{~cm}$. Error bars indicate standard errors of the mean and different letters indicate a significant difference. Note that the $y$-axis starts at $1.0 \mathrm{~g} \mathrm{~cm}^{-3}$ for clarity. 

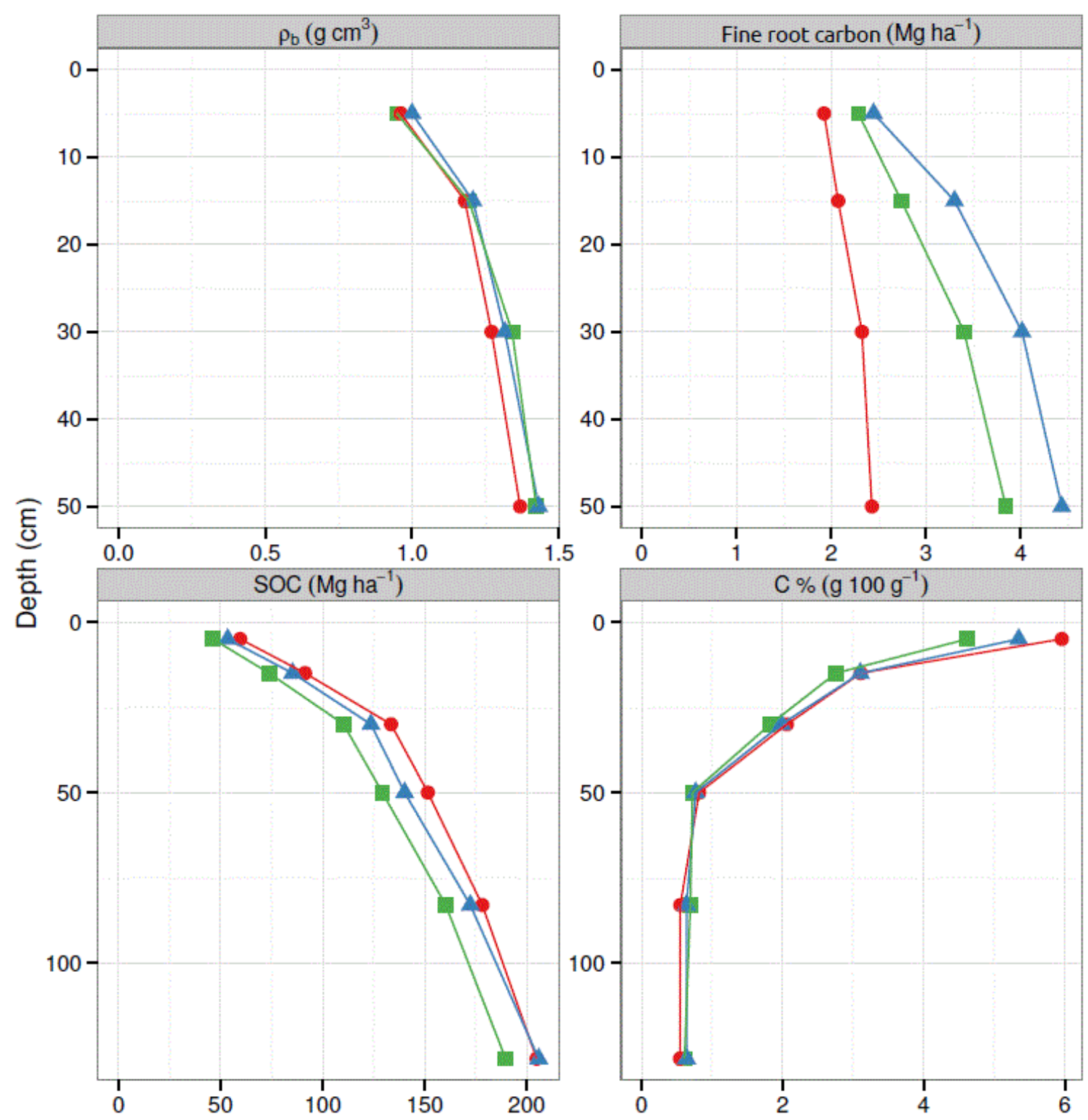

$\rightarrow$ Pasture $\_$Silvopastoral trees - -Woodland

Figure 3. Whole profile plots clockwise from top left: soil bulk density $\left(\rho_{\mathrm{b}}, \mathrm{g} \mathrm{cm}^{-3}\right)$, fine root carbon

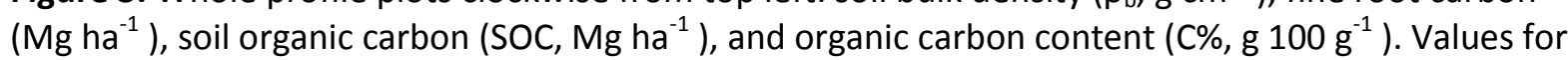
fine root carbon and soil organic carbon are cumulative from the surface.

Because the water contents determined from the bulk density samples were collected over a period of nine weeks, it was not possible to determine the effect of the treatments on soil moisture content. However the bulk density readings $\left(\rho_{b}\right)$ were negatively correlated $(p<$ $0.001, \mathrm{df}=330, \mathrm{R}^{2}=0.69$ ) with the gravimetric soil water content $\left(\theta_{\mathrm{g}}\right)$ (Figure 4 ). High bulk densities were associated with low gravimetric water contents. 


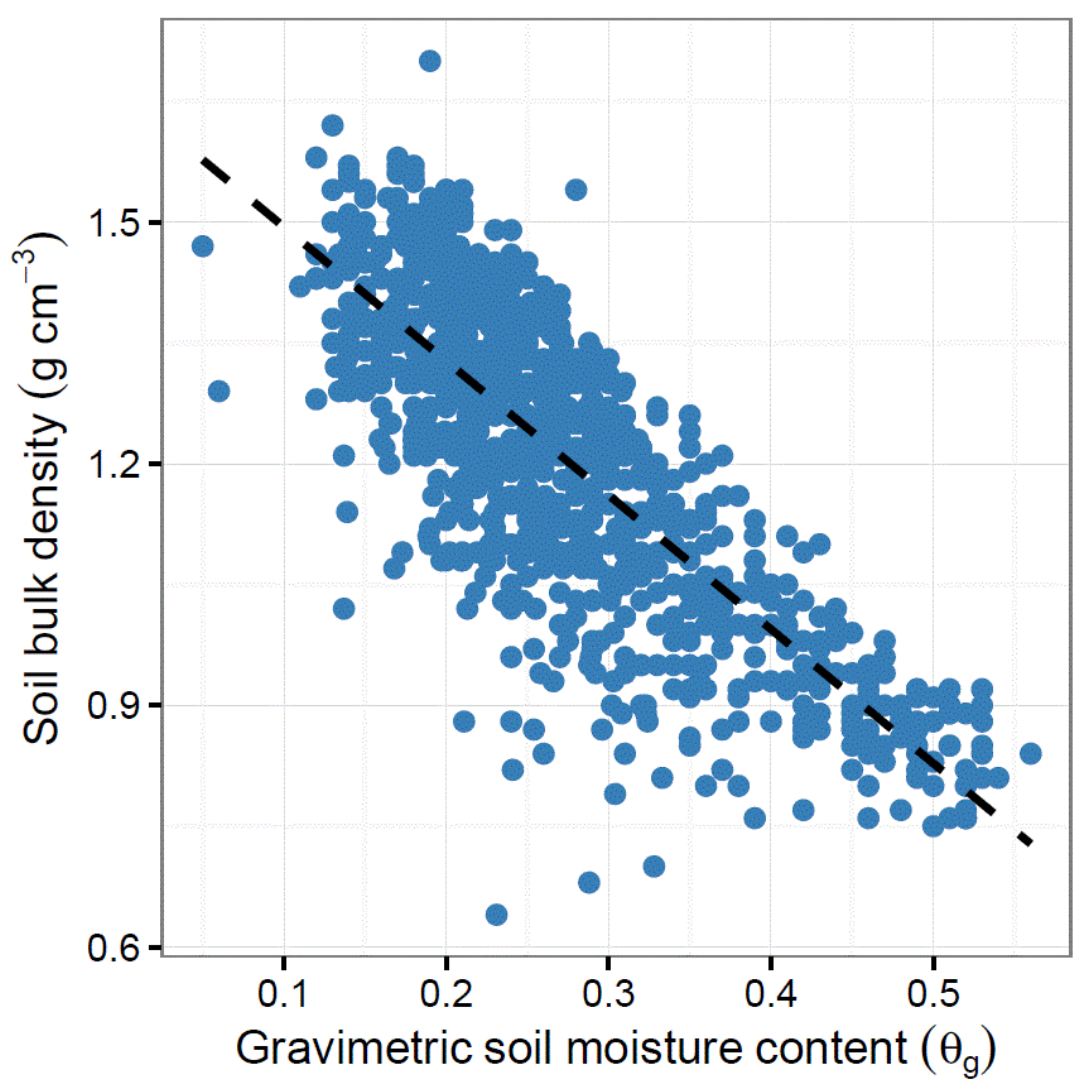

Figure 4. The effect of gravimetric moisture content $(\theta \mathrm{g})$ on soil bulk density for all samples collected in 2012 at Clapham Park. Dashed line follows the equation $y=1.674-1.71 x, R 2=0.69, n=332$.

Table 2. Analysis of variance (ANOVA) for soil bulk density, fine root mass density, organic carbon content (\%), and soil organic carbon ( $\left.\mathrm{Mg} \mathrm{ha}^{-1}\right)$ for the comparison of three treatments: pasture, silvopastoral trees, and woodland, and varying depths at Clapham Park in 2012. Degrees of freedom $(d f)$ and $\mathrm{F}$-values are given with significance denoted by stars: $\mathrm{p}<=0.001\left({ }^{* * *}\right), \mathrm{p}<=0.01\left({ }^{* *}\right), \mathrm{p}<=$ $0.05\left({ }^{*}\right), p>0.05$ (ns0. Note that it was necessary to transform the fine root mass density by a power of 0.2 in order to meet the normality assumptions of a linear model.

\begin{tabular}{lllllllll}
\hline \multirow{2}{*}{ Term } & \multicolumn{2}{l}{$\begin{array}{l}\text { Soil bulk } \\
\text { density }\end{array}$} & \multicolumn{2}{l}{$\begin{array}{l}\text { Fine root } \\
\text { mass density }\end{array}$} & \multicolumn{2}{l}{$\begin{array}{l}\text { Organic carbon } \\
\text { content }\end{array}$} & \multicolumn{2}{l}{ Soil organic carbon } \\
\cline { 2 - 9 } & $d f$ & F-value & $d f$ & F-value & $d f$ & F-value & $d f$ & F-value \\
\hline Block & 1 & & 1 & & 1 & & 1 & \\
Treatment & 1 & $14.12^{* * *}$ & 1 & $30.88^{* * *}$ & 1 & $2.88^{n s}$ & 1 & $0.25^{n s}$ \\
Depth & 3 & $400.03^{* * *}$ & 3 & $220.68^{* * *}$ & 5 & $1214.44^{* * *}$ & 5 & $118.61^{* * *}$ \\
Treat $\times$ depth & 6 & $1.52^{n s}$ & 6 & $1.85^{n s}$ & 10 & $8.25^{* * *}$ & 10 & $2.16^{*}$ \\
Residuals & 308 & & 308 & & 462 & & 462 & \\
\hline
\end{tabular}

Analysis of the volumetric water content $\left(\theta_{v}\right)$ obtained from the capacitance probe indicated highly significant differences between treatments $(p<0.001)$, and depths $(p<0.001)$ and the interaction between the two (Table 3$)$. The volumetric water content $\left(\mathrm{cm} \mathrm{cm}^{-3}\right)$ in the pasture $(0.593 \pm 0.003)$ was wetter $(p<0.05)$ than in the woodland $(0.565 \pm 0.003)$, and the driest soil was below the silvopastoral trees $(0.540 \pm 0.003)$. 
Table 3. ANOVA of volumetric water content $\left(\theta_{v}\right)$ for three treatments: pasture control, silvopastoral trees, and woodland at Clapham Park. Measurements were taken on nine occasions between 23 October 2013 and 19 March 2014. Degrees of freedom and F -values are given with significance denoted by stars: $\mathrm{p}<=0.001\left({ }^{* * *}\right), \mathrm{p}<=0.01\left({ }^{* *}\right), \mathrm{p}<=0.05\left({ }^{*}\right), \mathrm{p}>0.05$ (ns).

\begin{tabular}{lrr}
\hline Term & \multicolumn{1}{c}{$d f$} & \multicolumn{1}{c}{ F-value } \\
\hline Date & 1 & \\
Date $\times$ block & 1 & \\
Treatment & 2 & $111.07^{* * *}$ \\
Depth & 11 & $8.51^{* * *}$ \\
Treatment $\times$ depth & 22 & $3.38^{* * *}$ \\
Residuals & 858 & \\
\hline
\end{tabular}

\subsection{Fine root mass density}

Overall fine root mass density (FRMD) in pasture $\left(1.22 \pm 0.14 \mathrm{mg} \mathrm{cm}^{-3}\right)$ was lower than that than below the silvopastoral trees $\left(1.85 \pm 0.24 \mathrm{mg} \mathrm{cm}^{-3}\right)$ and woodland $\left(1.72 \pm 0.26 \mathrm{mg} \mathrm{cm}^{-3}\right.$ ), which had similar values (Figure 5). FRMD decreased with depth (Table 2 ) falling from $3.98 \pm 0.28 \mathrm{mg} \mathrm{cm}^{-3}$ at the soil surface $(0-10 \mathrm{~cm})$ to $0.34 \pm 0.04 \mathrm{mg} \mathrm{cm}^{-3}$ at the deepest depth increment $(40-60 \mathrm{~cm})$. There was no treatment $x$ depth interaction. 


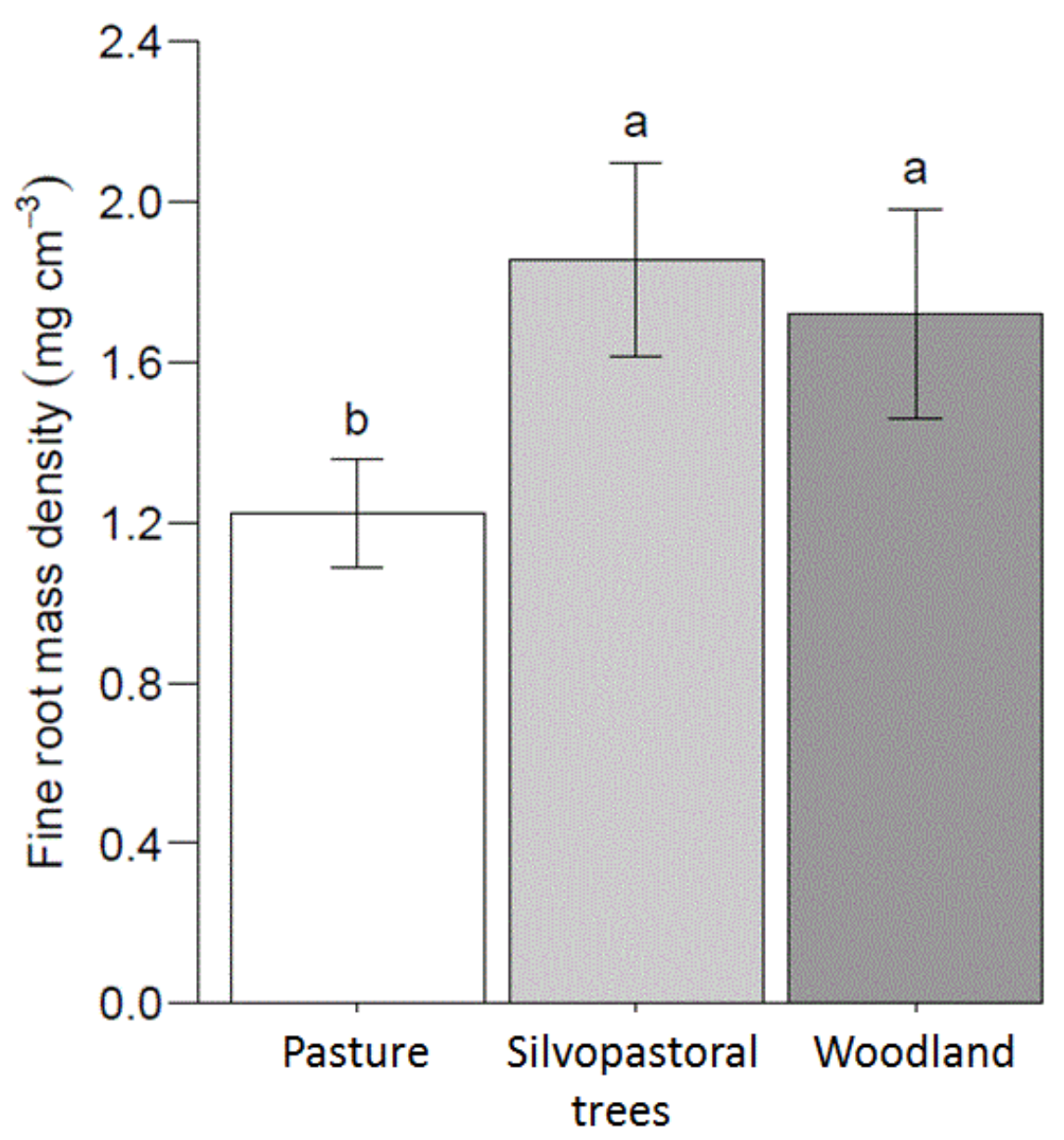

Figure 5. Fine root mass density (FRMD) for the pasture $(n=160)$, silvopastoral tree $(n=80)$, and woodland $(n=80)$ treatments. Bars represent mean of all depth increments: $0-10 \mathrm{~cm}, 10-20 \mathrm{~cm}$, 20-40 cm, and 40-60 cm. Error bars indicate standard errors of the mean, different letters indicate a significant difference.

\subsection{Organic carbon content and carbon stock}

Fourteen years after planting, there were significant $(p<0.001)$ depth and treatment interactions on soil organic carbon contents (Table 2). At a depth of $0-10 \mathrm{~cm}$, the organic

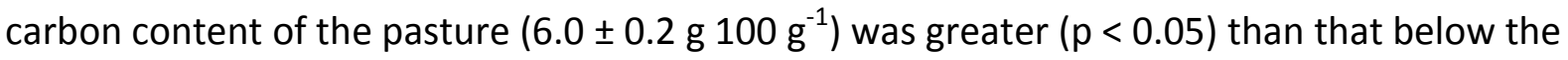

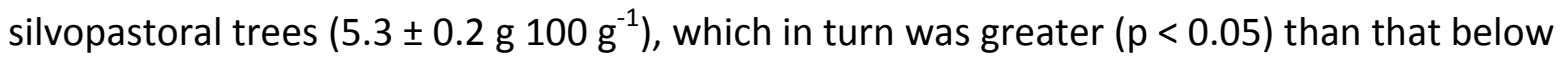

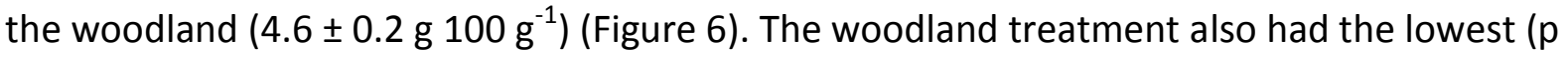
$<0.05)$ organic carbon content at 10-20 cm. Below $20 \mathrm{~cm}$, there were no $(p>0.05)$ treatment differences in organic carbon content at individual depth increments. Considered over the full depth, the mean level of organic carbon content in the three treatments were similar $(p=0.091$, Table 2$)$. 


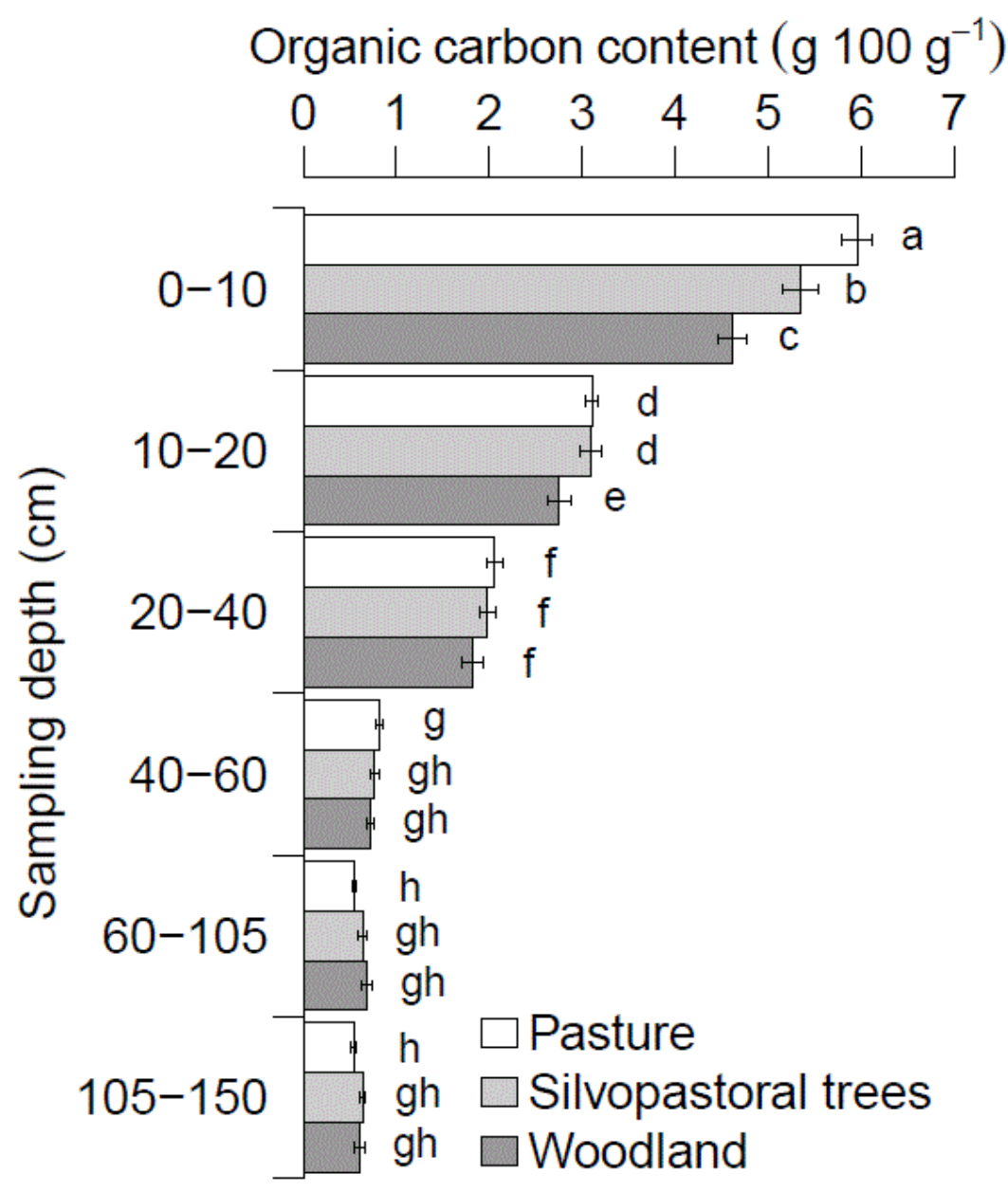

Figure 6. Organic carbon content at each of six depth increments in the pasture $(n=40)$, silvopasture tree $(n=20)$, and woodland $(n=20)$ treatments at Clapham Park in 2012. Error bars indicate standard errors of the means.

The SOC stock was considered on an equivalent soil mass (ESM) basis (Ellert and Bettany, 1995) to take into account treatment effects on soil volume. In the uppermost 0-10 cm increment the SOC stock stored below the pasture $\left(59.6 \pm 1.6 \mathrm{Mg} \mathrm{ha}^{-1}\right)$ was greater $(p<$ $0.05)$ than that below the silvopastoral trees $\left(53.5 \pm 2.0 \mathrm{Mg} \mathrm{ha}^{-1}\right)$ and the woodland $(46.2 \pm$ 1.6 $\mathrm{Mg} \mathrm{ha}^{-1}$ ) (Figure 7). Below this level no statistically significant difference was found on either an increment or a cumulative basis (Table 4). In the $10-20 \mathrm{~cm}$ increment the SOC stock below the pasture and silvopasture trees were similar $\left(31.7 \pm 1.0 \mathrm{Mg} \mathrm{ha}^{-1}\right.$ and $31.8 \pm$ $1.4 \mathrm{Mg} \mathrm{ha}^{-1}$ respectively) and the equivalent SOC stock in the woodland was $27.6 \pm 1.2 \mathrm{Mg}$ ha ${ }^{-1}$ (Figure 7). 
Table 4. Summary of $F$-values and significance (denoted by stars: $p<=0.001\left({ }^{* * *}\right), \mathrm{p}<=0.01\left({ }^{* *}\right), \mathrm{p}$ $<=0.05\left({ }^{*}\right), p>0.05$ (ns).) for ANOVA of soil organic carbon stock for a) individual depth increments and b) cumulative depth increments in the three treatments (pasture control, silvopastoral trees, and woodland) at Clapham Park. Each F -value is derived from a separate ANOVA.

\begin{tabular}{|c|c|c|c|c|c|c|c|}
\hline & \multicolumn{7}{|c|}{ Depth (cm) } \\
\hline Term & $d f$ & $0-10$ & $10-20$ & $20-40$ & $40-60$ & $60-105$ & $105-150$ \\
\hline Block & 1 & & & & & & \\
\hline Treatment & 1 & $5.96 *$ & $<0.01^{n s}$ & $1.54^{n s}$ & $0.22^{n s}$ & $2.91^{n s}$ & $2.38^{n s}$ \\
\hline \multirow[t]{2}{*}{ Residual } & 77 & & & & & & \\
\hline & Cur & depth ( & & & & & \\
\hline Term & $d f$ & $0-10$ & $0-20$ & $0-40$ & $0-60$ & $0-105$ & $0-150$ \\
\hline Block & 1 & & & & & & \\
\hline Treatment & 1 & $5.96^{*}$ & $2.45^{n s}$ & $2.79^{n s}$ & $2.41^{n s}$ & $0.46^{n s}$ & $<0.01^{\text {ns }}$ \\
\hline Residual & 77 & & & & & & \\
\hline
\end{tabular}

The SOC stock measurements from the mature silvopastoral system at Helen's Wood were not included in statistical analyses because the level of replication was low ( $n=3$ per depth). However the SOC has been included in Figure 7 as a point of reference with $95 \%$ confidence intervals. Whilst the confidence intervals are large for the deeper depth increments, the sample mean SOC stock in the mature grazed woodland was larger than the other treatments at $0-10 \mathrm{~cm}$ and $10-20 \mathrm{~cm}$. 

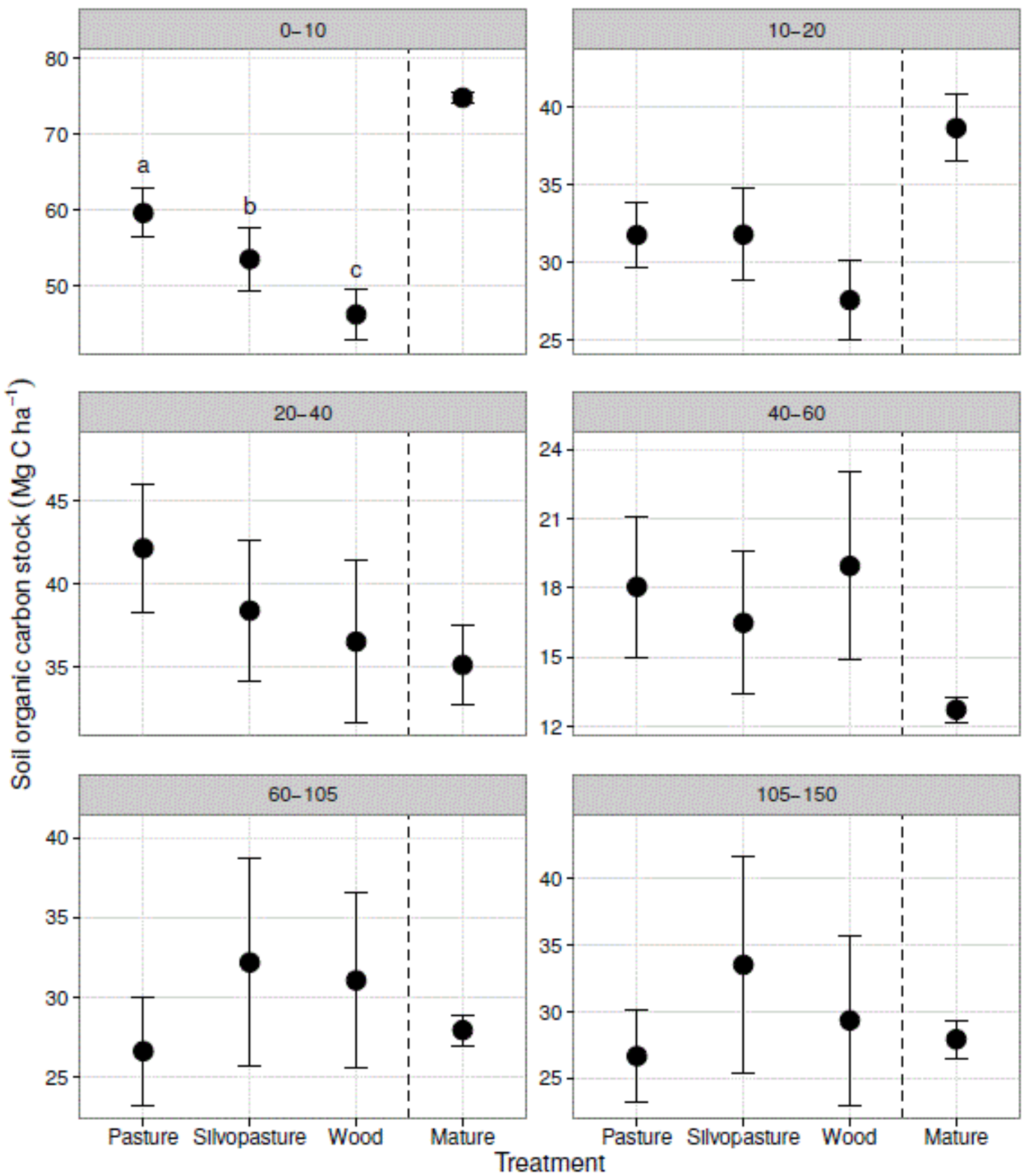

Figure 7. Comparison of soil organic carbon (SOC) stock measurements $\left(\mathrm{Mg} \mathrm{ha}^{-1}\right)$ for the six depth layers $(0-10 \mathrm{~cm}$ to $105-150 \mathrm{~cm})$ taken in the pasture $(n=40)$, silvopasture tree $(n=20)$ and woodland $(n=20)$ treatments with measurements taken in a nearby mature grazed woodland $(n=$ 3). Error bars show $95 \%$ confidence intervals. Letters indicate a significant difference where appropriate; the mature grazed woodland was not included in statistical analyses due to the low level of replication.

\subsection{Carbon fractionation}

Results from carbon fractionation were highly variable (Table 5) and there was no $(p<0.05)$ treatment, depth, or interaction effect. The level of organic carbon in the rSOC fraction below the silvopastoral trees and the woodland was occasionally below the detection limit of the elemental analyser. 
Table 5: Mean $( \pm S E)$ proportion of total sample organic carbon content contained within each fraction resulting from the Zimmermann et al. (2007) fractionation procedure in the pasture, silvopastoral trees, and woodland treatments. The fractions are: dissolvable organic carbon fraction (DOC), particulate organic matter (POM), chemically resistant soil organic carbon ( $\mathrm{rSOC}$ ), sand and stable aggregates $(\mathrm{S}+\mathrm{A})$, and silt and clay minus the chemically resistant soil organic carbon ( $\mathrm{s}+\mathrm{c}-$ rSOC). No significant differences were detected $(n=3)$. Values of $r S O C$ were very low, at times below the detection limit of the elementar analyser. Zero values have been excluded hence, at times $n=1$ and therefore a standard error is not available.

\begin{tabular}{|c|c|c|c|c|c|c|}
\hline \multirow{3}{*}{$\begin{array}{l}\text { Fraction } \\
\text { and depth (cm) } \\
\text { DOC }\end{array}$} & \multicolumn{6}{|c|}{ Proportion of total sample organic carbon content (\%) } \\
\hline & \multicolumn{2}{|c|}{ Pasture } & \multicolumn{2}{|c|}{ Silvopastoral trees } & \multicolumn{2}{|c|}{ Woodland } \\
\hline & & & & & & \\
\hline $0-10$ & 1.4 & \pm 0.6 & 1.8 & \pm 0.4 & 1.7 & \pm 0.5 \\
\hline $10-20$ & 1.8 & \pm 0.7 & 1.7 & \pm 0.2 & 1.5 & \pm 0.6 \\
\hline \multicolumn{7}{|l|}{ POM } \\
\hline $0-10$ & 18.1 & \pm 3.4 & 16.9 & \pm 4.9 & 19.7 & \pm 1.3 \\
\hline $10-20$ & 14.7 & \pm 4.6 & 18.4 & \pm 4.7 & 10.9 & \pm 1.1 \\
\hline \multicolumn{7}{|l|}{ rSOC } \\
\hline $0-10$ & 0.3 & \pm 0.0 & 0.3 & _ & 0.1 & _ \\
\hline $10-20$ & 0.4 & \pm 0.1 & 0.4 & 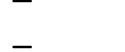 & 0.1 & - \\
\hline \multicolumn{7}{|l|}{$S+A$} \\
\hline $0-10$ & 14.3 & \pm 1.2 & 9.8 & \pm 2.0 & 11.5 & \pm 1.7 \\
\hline $10-20$ & 9.5 & \pm 1.8 & 9.9 & \pm 2.8 & 12.1 & \pm 2.7 \\
\hline \multicolumn{7}{|l|}{$s+c-r S O C$} \\
\hline $0-10$ & 66.1 & \pm 3.1 & 71.4 & \pm 5.7 & 67.1 & \pm 2.5 \\
\hline $10-20$ & 73.9 & \pm 4.0 & 69.9 & \pm 5.3 & 75.6 & \pm 2.9 \\
\hline
\end{tabular}

\subsection{Power analyses}

Power analyses were conducted to determine the actual rate of SOC change that would be required to have a less than a $20 \%(\beta=0.2)$ chance of wrongly concluding that there was no difference between treatments. This was completed for different numbers of soil samples at each of the six soil depth increments (0-10 to 105-150) (Figure 8a) and each of six cumulative soil depth $(0-10$ to $0-150 \mathrm{~cm}$ ) (Figure $8 \mathrm{~b})$. For example the change of $14.7 \mathrm{Mg}$ $\mathrm{ha}^{-1}$ (equivalent to $1 \mathrm{Mg} \mathrm{ha}^{-1} \mathrm{a}^{-1}$ ) observed in the $0-10 \mathrm{~cm}$ increment could be established (whilst maintaining $\beta$ at 20\%) (Table 6) with paired samples from 9 plots (Figure 8 ). By considering only the effect at individual depth increments, the change of $4.2 \mathrm{Mg} \mathrm{ha}^{-1}$ at 10 $20 \mathrm{~cm}$ (equivalent to $0.3 \mathrm{Mg} \mathrm{ha}^{-1} \mathrm{a}^{-1}$ ) would require 42 paired samples (Figure 8a). By contrast the number of samples required to avoid type II errors with the cumulative SOC stock measurements was less. For example $\beta$ could be maintained at $20 \%$ for the $23.7 \mathrm{ha}^{-1}$ observed over the $0-40 \mathrm{~cm}$ depth with 15 paired samples (Table 6). 

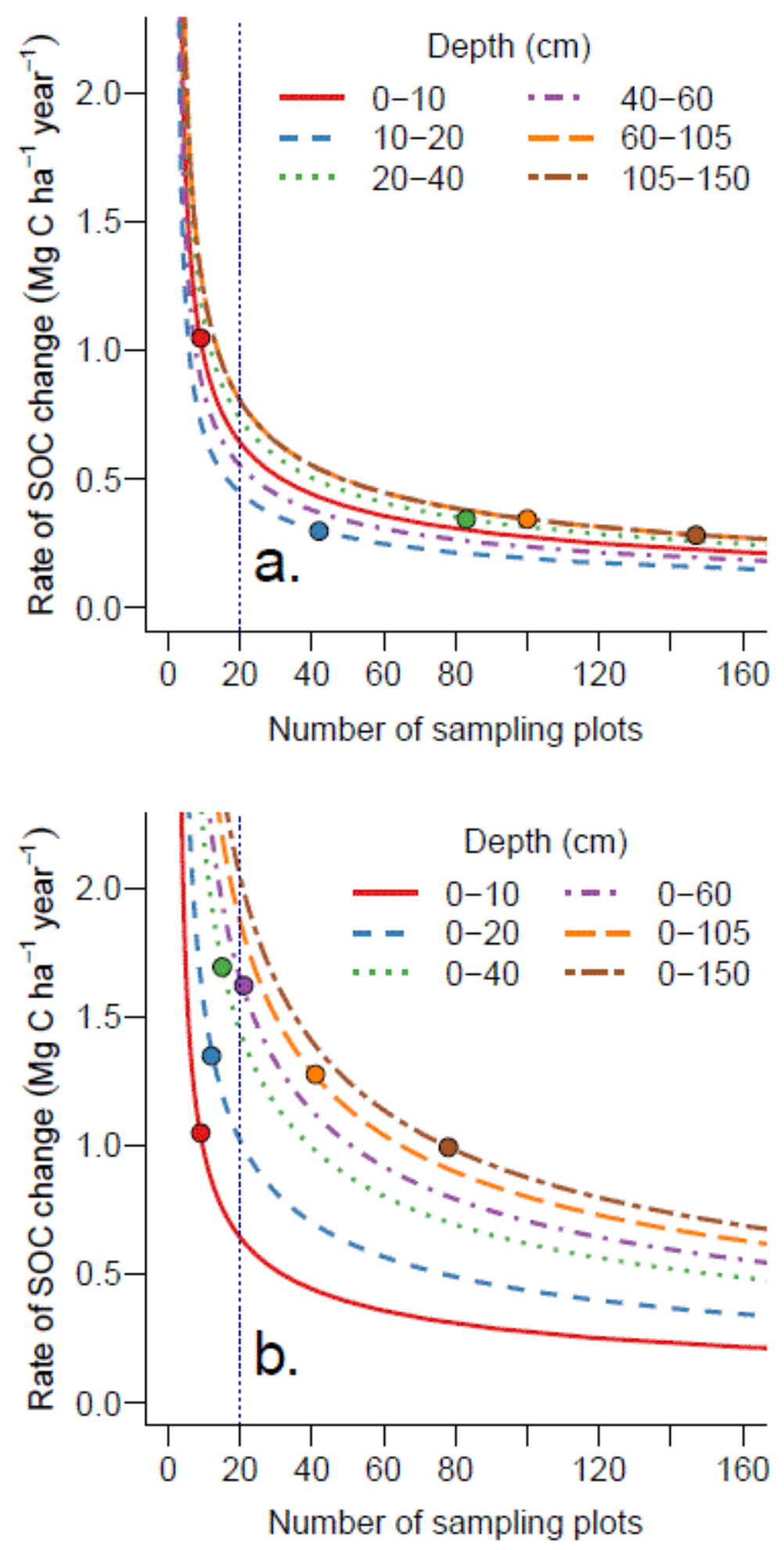

Figure 8. Lines show the rate of soil organic carbon (SOC) change $\left(\mathrm{Mg} \mathrm{ha}^{-1} \mathrm{a}^{-1}\right)$ that could be detected for a number of paired sampling points over a) individual depth increments and b) cumulative depth increments after 14 years, whilst maintaining a type I error rate $(\alpha)$ of 0.05 and a type II error rate $(\beta)$ of 0.2 . The results are based 20 plots from each of the pasture and woodland treatments at Clapham Park - see methods. The datum points on each depth curve relate to the actual SOC sequestration rates detected in the Clapham Park experiment. The $x$-axis on plot a. has been truncated at $x=160$; one point $(40-60 \mathrm{~cm})$ lies at $x=1067$. The dotted line at 20 sampling plots indicates the minimum number of replicates completed in the current experiment. 
Table 6. Mean change in $\mathrm{SOC}$ (with standard deviation) in each individual and cumulative depth increment from the pasture to the woodland treatment. The annual rate of SOC change and coefficient of variation is also given along with the output from power analysis assuming a similar sampling system to that employed here is used. The number of paired plots $\left(n_{\text {plots }}\right)$ and the actual number of samples ( $\left.n_{\text {samples }}\right)$ that are required to have maintained $\beta=0.2$ given the differences between treatments are also presented. Note that for a cumulative depth of $0-150 \mathrm{~cm}$, there are six depths, hence a single sampling plot to this depth would equate to twelve samples.

\begin{tabular}{lrrrrrr}
\hline Depth (cm) & $\begin{array}{l}\text { SOC change } \\
\left(\mathrm{Mg} \mathrm{ha}^{-1}\right)\end{array}$ & $\begin{array}{l}\text { Standard } \\
\text { deviation } \\
\left(\mathrm{Mg} \mathrm{ha}^{-1}\right)\end{array}$ & $\begin{array}{l}\text { SOC change } \\
\left(\mathrm{Mg} \mathrm{ha}^{-1} \mathrm{a}^{-1}\right)\end{array}$ & $\begin{array}{l}\text { Coefficient } \\
\text { of variation } \\
(\%)\end{array}$ & $n_{\text {plots }}$ & \\
& -14.7 & 13.6 & -1.0 & -0.9 & 9 & 18 \\
\hline $0-10$ & -4.2 & 9.5 & -0.3 & -2.3 & 42 & 84 \\
$10-20$ & -4.8 & 15.6 & -0.3 & -3.2 & 83 & 166 \\
$20-40$ & 1.0 & 11.7 & 0.1 & 11.6 & 1067 & 2134 \\
$40-60$ & 4.8 & 17.1 & 0.3 & 3.5 & 100 & 200 \\
$60-105$ & 4.0 & 17 & 0.3 & 4.3 & 147 & 294 \\
$105-150$ & & & & & & \\
\hline & -14.7 & 13.6 & -1.0 & -0.9 & 9 & 18 \\
$0-10$ & -18.9 & 21.6 & -1.3 & -1.1 & 12 & 48 \\
$0-20$ & -23.7 & 30.5 & -1.7 & -1.3 & 15 & 90 \\
$0-40$ & -22.7 & 34.9 & -1.6 & -1.5 & 21 & 168 \\
$0-60$ & -17.9 & 39.6 & -1.3 & -2.2 & 41 & 410 \\
$0-105$ & -13.9 & 43.3 & -1.0 & -3.1 & 78 & 936 \\
$0-150$ & & & & &
\end{tabular}

\section{Discussion}

The results are discussed in terms of the changes in soil organic carbon, possible reasons for the effect of tree planting, overall carbon storage, and methods for reporting changes in soil carbon stocks and power analysis. We also include a brief discussion of the results from the carbon fractionation and the mature silvopastoral system.

\subsection{Change in soil organic carbon}

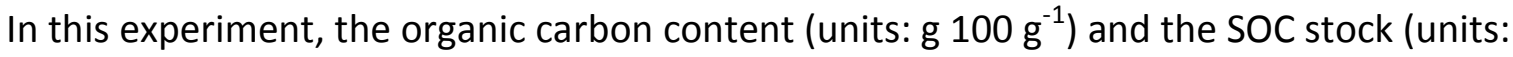
$\mathrm{Mg} \mathrm{ha}^{-1}$ ) of the pasture was greater than that of the tree planted treatments in the surface soil layer $(0-10 \mathrm{~cm})$. The mean SOC stocks in the surface layer of the silvopastoral trees and the woodland were 0.90 and 0.78 of that in the pasture respectively. Our findings agree with those of Shi et al. (2013) who report that the response ratio (defined as the new SOC stock divided by the SOC stock of the control at each depth) in studies of tree planting on grasslands tended to be below 1.00 but not significantly different from 1.00 .

In 2011, a voluntary scheme called the Woodland Carbon Code was introduced in the UK to encourage woodland creation for sequestration benefits (Forestry Commission, 2013). The scheme allows for carbon accumulated in biomass, litter and deadwood, non-tree biomass, 
and the soil to be quantified, and used to calculate a net benefit in terms of sequestered carbon. Soil carbon changes are included in the Woodland Carbon Code, either by a laboratory based soil carbon assessment, or by calculations determined from 'baseline' values derived from Bradley et al. (2005). Because of the uncertainty in the effect of afforestation on SOC stocks, the Woodland Carbon Code currently assumes no change in SOC stores following tree planting on grassland (West, 2011). The results presented here support that the existing assumption that tree planting on lowland grassland does not increase soil carbon stocks.

The observed calculated rate of SOC loss in the surface layer $(0-10 \mathrm{~cm})$ of the woodland is high; equivalent to an annual loss of $1.0 \mathrm{Mg} \mathrm{ha}^{-1}$ over 14 years. As indicated in the introduction, tree planting will result in increased above ground carbon storage compared to grassland. As detailed in the Appendix, an assessment was made of the above-ground carbon storage 14 years after tree planting. The above ground storage of the woodland trees was $35.9 \mathrm{Mg} \mathrm{ha}^{-1}$, equivalent to an annual increment of $2.56 \mathrm{Mg} \mathrm{ha}^{-1} \mathrm{a}^{-1}$. Hence although woodland planting increased carbon sequestration, during the first 14 years, the SOC losses in the $0-10 \mathrm{~cm}$ layer would alone offset $37 \%$ of the above ground gain.

There was also a loss of SOC stock in the surface layer $(0-10 \mathrm{~cm})$ of the silvopastoral trees of $6.1 \mathrm{Mg} \mathrm{ha}^{-1}$, equivalent to a mean loss of $0.44 \mathrm{Mg} \mathrm{ha}^{-1} \mathrm{a}^{-1}$ over the 14 years. However the above ground carbon storage of the silvopastoral trees was higher than the woodland, equivalent to $99.4 \mathrm{Mg} \mathrm{ha}^{-1}$ (7.1 Mg ha ${ }^{-1} \mathrm{a}^{-1}$ ) when expressed in relation to the tree spacing of the silvopasture. Hence in this case the SOC losses in the surface soil layer would reduce the net carbon gain within the area of the silvopastoral trees by $6 \%$.

\subsection{Explaining the effect of tree planting}

Possible explanations for the observed decline in SOC below the silvopastoral trees and woodland, compared to the pasture, include pre-experimental variation across the site, preplanting disturbance, changes in ground vegetation, and bulk density and soil water effects. These are considered in turn.

No soil carbon measurements were taken before tree planting and it was not possible to implement a split plot design, so it is impossible to completely rule out a pre-existing gradient of soil carbon. However, we consider this to be unlikely for two reasons. Firstly records demonstrate that the entire site had been under the same management for at least 200 years prior to tree planting. Secondly, it is improbable that the 20 randomly selected silvopastoral tree blocks would show a systematic decline in carbon compared to the pasture. Whilst treatment related bulk density changes can cause changes in SOC stock, these effects were mitigated by the use of the equivalent soil mass method to determine SOC changes. 
High levels of pre-planting disturbance can result in slower gains (and even losses) of soil carbon (Laganiere et al., 2010). However, the trees at Clapham Park were all planted by hand (Burgess et al., 2000) and there was no pre-planting preparation of the soil. Hence the disturbance effect is expected to be minimal.

The loss of perennial grass cover in the woodland could explain the observed decline in SOC (Figure 9). This is consistent with intermediate soil carbon content below the silvopastoral trees where large amounts of solar radiation is able to reach the understorey from the sides of the silvopastoral blocks. Hence although there was a loss of grass cover compared to the open pasture, a less dense grass understorey was maintained under the silvopastoral trees throughout the year (Figure 9). By contrast in the woodland, the extensive ground cover primarily of Gallium aparine L. observed in April-May had died by August-September (Figure 9).

Our measurements showed that fine root mass densities (FRMD) below the woodland and the silvopastoral trees were $40 \%$ and $52 \%$ larger respectively than the below the pasture. We did not measure fine root length density, but Upson and Burgess (2013) in a different agroforestry experiment in Bedfordshire, reported the specific root density within a pasture $\left(175 \mathrm{~m} \mathrm{~g}^{-1}\right)$ was greater than within an agroforestry area $\left(60-69 \mathrm{~m} \mathrm{~g}^{-1}\right)$. It could be argued that thinner roots in the grassland could have a faster turnover rate, higher rates of root exudates and root tip attrition, which contribute more carbon. Rasse et al. (2005) argues that small roots can also be more easily adopted into organo-mineral complexes and thereby protected from decomposition (Rasse et al., 2005). At this stage of tree establishment, just 14 years after planting, it is arguable that inputs from grass continue to be the dominant source of soil carbon. Hence soil carbon was reduced below the silvopastoral trees where there was a decline in grass cover, and was substantially reduced below the woodland where the grass has been completely shaded out.
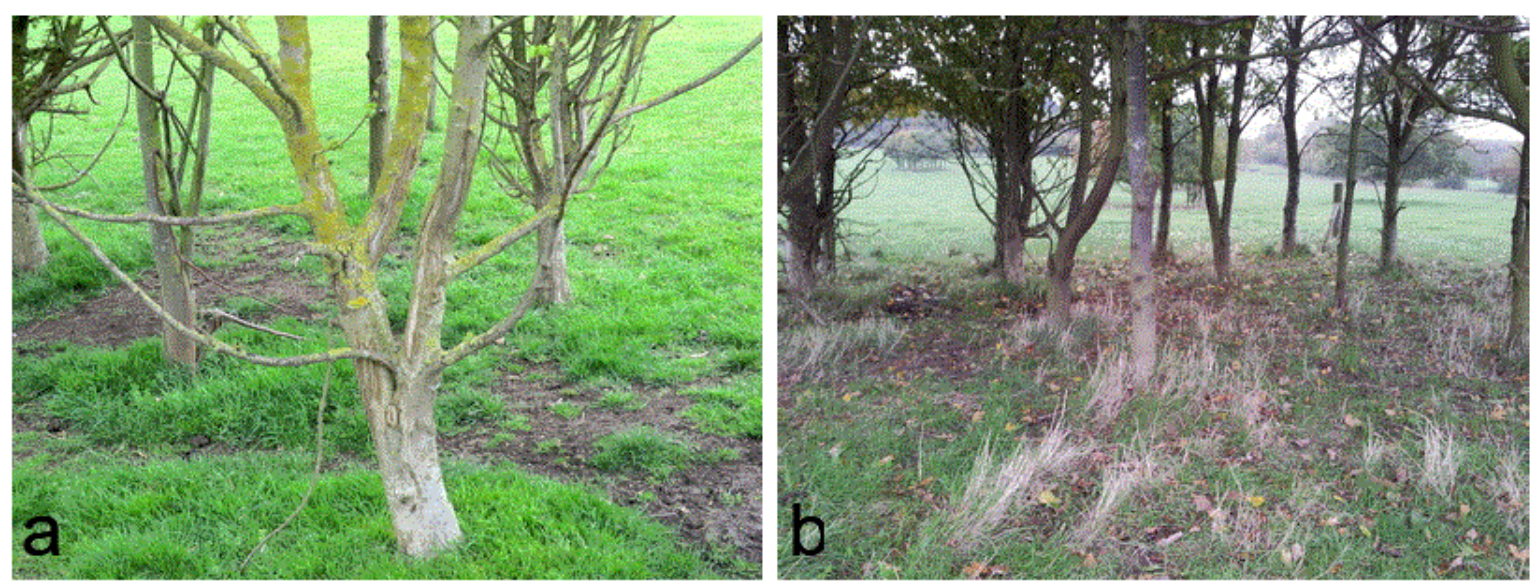

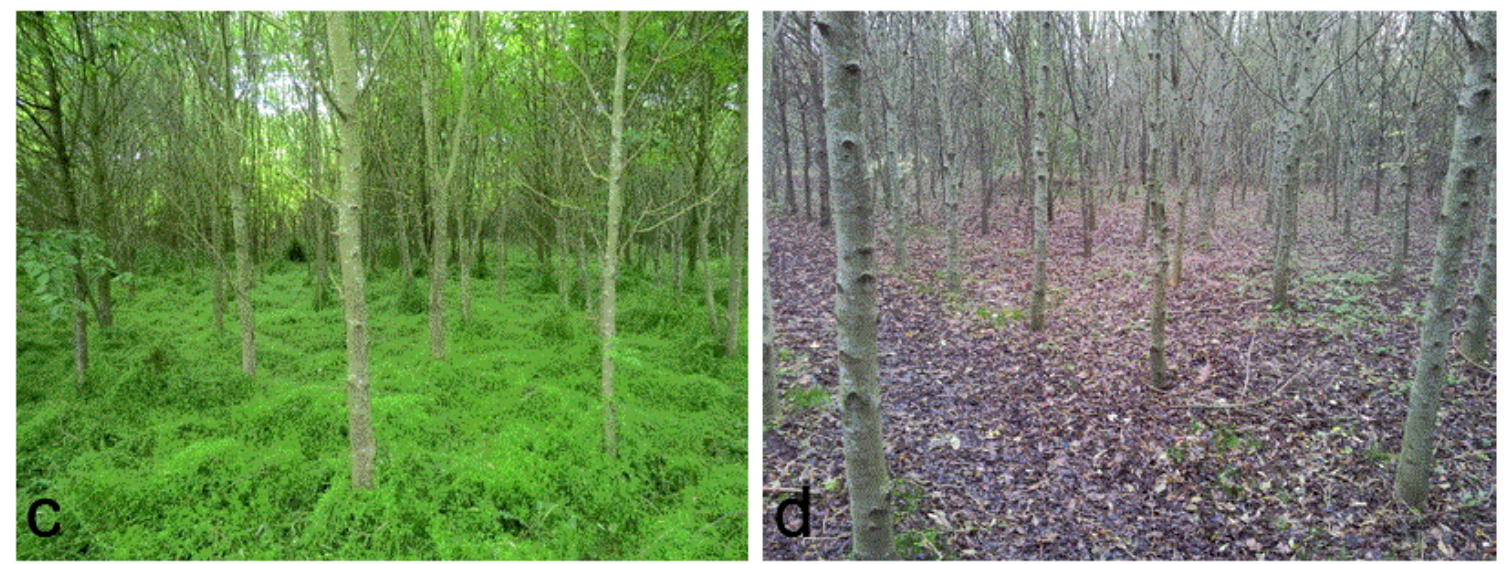

Figure 9. Ground vegetation in silvopasture tree and the woodland plots in April and November. Despite an early mat of annual herbs, the woodland treatment was largely devoid of ground vegetation by November. Whilst some silvopastoral tree plots lost grass cover to trampling by livestock through the winter, in general a strong grass layer was maintained throughout the year. a) April 2012: facing north from the centre of a plot of silvopastoral trees. Note some loss of grass due to trampling by livestock.

b) November 2013: within a silvopastoral tree plot, grass dominated the field layer throughout the year.

c) April 2012: in this photo taken near to woodland sampling point 1 (facing South), vegetation was almost exclusively composed of Galium aparine.

d) November 2013: at this time the woodland was almost totally devoid of ground storey vegetation, with the exception of occasional tufts of grass, herb robert (Geranium robertanium) and tree seedlings.

The results indicate that tree planting was also associated with an increase in the bulk density of the clay soil. One possible reason for this is that the trees had reduced the soil water content (Figure 4). Certainly the volumetric soil water contents, measured using a capacitance probe, were lower beneath the trees than the grass. This in turn could be a result of greater transpiration by the trees or greater rainfall interception compared to the pasture. Davidson et al. (1998) have reported that beyond an initial threshold, soil respiration rates (and thus decomposition and potentially $C$ loss) can increase with soil drying in temperate hardwood forests. Hence if low soil water contents do increase soil respiration, then the observed lower soil water content could lead to a lower SOC stock.

\subsection{Overall carbon storage}

In this experiment the silvopastoral trees occupied $4 \%$ of the overall pasture area. Hence assuming that the SOC of the pasture, woodland, and silvopasture trees are representative of their respective areas, the carbon storage of the overall silvopastoral system was $63.4 \mathrm{Mg}$ $\mathrm{ha}^{-1}$ (Table 7). By comparison, the simple combination of $96 \%$ of the carbon storage in the pasture and $4 \%$ of the woodland would result in total carbon storage of $60.5 \mathrm{Mg} \mathrm{ha}^{-1}$. These results suggest that the silvopastoral system could store more carbon than equivalent areas of trees and pasture in separate blocks. This increased carbon storage of the silvopastoral system can be explained by greater capture of resources such as solar radiation and water 
by combining two vegetation types. Even though the silvopasture trees were planted at a closer spacing $(2 \mathrm{~m} \times 2 \mathrm{~m})$ than the woodland trees $(2.5 \mathrm{~m} \times 2.5 \mathrm{~m})$, it is anticipated that each individual silvopasture tree was able to intercept more solar radiation than an equivalent woodland tree, particularly when the sun was not overhead.

Table 7. Predicted tree biomass carbon and soil organic carbon storage of the woodland, silvopastoral and pasture systems and a pro-rata system equivalent to $96 \%$ pasture and $4 \%$ woodland.

\begin{tabular}{|c|c|c|c|c|}
\hline & Pasture & $\begin{array}{l}\text { Silvopasture } \\
\text { system }\end{array}$ & Woodland & $\begin{array}{l}\text { Pro-rata system of } \\
96 \% \text { pasture and } 4 \% \\
\text { woodland }\end{array}$ \\
\hline Tree biomass $\mathrm{C}$ storage $\left(\mathrm{Mg} \mathrm{ha}^{-1}\right)$ & $0.0^{\mathrm{b}}$ & $4.0^{\mathrm{a}}$ & 35.9 & 1.4 \\
\hline Soil organic carbon storage $\left(\mathrm{Mg} \mathrm{ha}^{-1}\right)$ & 59.6 & $59.4^{c}$ & 46.2 & 59.1 \\
\hline Total $\left(\mathrm{Mg} \mathrm{ha}^{-1}\right)$ & 59.6 & 63.4 & 82.1 & 60.5 \\
\hline \multicolumn{5}{|c|}{$\begin{array}{l}{ }^{2} \text { Tree biomass carbon in the silvopasture is equivalent to } 4 \% \text { of } 99.4 \mathrm{Mg} \mathrm{ha}^{-1}=4.0 \mathrm{Mg} \mathrm{ha}^{-1} \\
{ }^{\mathrm{b}} \text { Tree biomass carbon storage in the pasture is assumed to be } 0 \text {. } \\
{ }^{\mathrm{c} S} \text { Soil organic carbon storage in the silvopasture is equivalent to } 4 \% \text { of } 53.5 \mathrm{Mg} \mathrm{ha}^{-1} \text { and } 96 \% \text { of } 59.6 \\
\mathrm{Mg} \mathrm{ha}^{-1}=59.4 \mathrm{Mg} \mathrm{ha}^{-1}\end{array}$} \\
\hline \multicolumn{5}{|c|}{$\begin{array}{l}\text { These simple calculations do not include the likely residence time of the carbon stored in } \\
\text { the biomass and soil pools. One possible method to address this is to consider above- and } \\
\text { below-ground carbon storage in terms of "carbon-years": the change in carbon multiplied } \\
\text { by the mean residence time of each pool. This would allow the value of carbon stocks in } \\
\text { different pools to be compared more equitably. Of course this approach would require both } \\
\text { characterisation of biomass and soil carbon pools, and the likely residence time of C within } \\
\text { them, neither of which is simple. }\end{array}$} \\
\hline
\end{tabular}

\subsection{Methods of reporting SOC stocks and statistical power}

This experiment attempted to determine if there was a change in SOC to a depth of $150 \mathrm{~cm}$. In principle it is important to establish if there is change at such depths as $30 \%$ of the organic carbon in the $150 \mathrm{~cm}$ profile was found at depths greater than $60 \mathrm{~cm}$. However as found in meta-analyses, for example by Shi et al. (2013), we were unable to determine a statistically significant change in $\mathrm{SOC}$ stock below $40 \mathrm{~cm}$.

Changes in SOC stock can be described on the basis of soil increments or the cumulative stock to a specified depth. An alternative method to report changes, suggested by Kravchenko and Robertson (2011), is to determine the change in the cumulative SOC stock only from those depth increments showing significant differences. In this experiment, as the only significant difference was observed at 0-10 cm, the cumulative change over 0-150 $\mathrm{cm}$ (according to the Kravchenko and Robertson method) equates to the change at $0-10 \mathrm{~cm}$, i.e. the SOC of the pasture was $13.4 \mathrm{Mg} \mathrm{ha}^{-1}$ higher than the woodland and $6.4 \mathrm{Mg} \mathrm{ha}^{-1}$ higher than below the silvopastoral trees. Soil carbon studies are always going to run the risk of low experimental power, as the magnitude of the variation between sampling points and depths is high relative to the magnitude of changes in the SOC stock. In particular 
because the mean changes in soil carbon decline with depth and the level of variation increases, it is particularly difficult to detect differences at depth. In this experiment we collected 480 samples per treatment, 120 each in the woodland and silvopasture trees, and 240 in the pasture. However the power analysis indicates that for the SOC stock within depth increments below $10 \mathrm{~cm}$ and at cumulative depths below 0-40 cm, there was more than a $20 \%$ chance of falsely concluding no difference between treatments (Figure 8 ).

Most soil carbon studies do not sample as intensively as we have and therefore almost certainly (and mostly unknowingly) run into low-power problems. Our findings highlight the importance of conducting appropriate post-hoc power analyses when reporting a negative result. Note however that using the so called 'observed power' in many proprietary statistical packages is not informative (Hoenig and Heisey, 2001; Thomas, 1997). In Figure 8 we present a 'reverse power analysis' (Thomas, 1997) - using the acceptable level of power $(1-\beta=0.8)$ and the observed variance from each depth layer to calculate the detectable effect size for a given sample size. These curves can be considered as a guide for future studies when comparing afforestation of pasture on clay soils in a temperate environment, though it would always be preferable to complete a site specific ad-hoc power analysis informed by a pilot study prior to any serious sampling endeavour.

Based on this analysis, to detect a rate of SOC change of $1 \mathrm{Mg} \mathrm{ha}^{-1} \mathrm{a}^{-1}$ (which was the rate observed) to $150 \mathrm{~cm}$, if one were to follow the suggestion of Kravchenko and Robertson (2011) and consider each depth layer individually (and thus satisfying the $\beta=0.2$ constraint for each depth layer) would require 1448 paired sampling plots (2896 individual samples). Considered cumulatively, the same analysis would require 78 paired plots (12 individual samples each: 936 individual samples, Table 6) to maintain $\beta=0.2$.

The Kravchenko and Robertson (2011) method for calculating SOC stocks offers an improvement on the more traditional cumulative method insofar as it reduces the likelihood of masking of treatment effects at individual depth increments by other layers. But far from increasing power and reducing the sampling requirement, the high ratio of standard deviation to the mean (CV, Table 6) at individual depth increments requires more sampling ( $n=2896$ individual samples) to maintain an acceptable type II error rate across the whole depth profile (Figure 8). This does not mean that researchers should not use the method, but must be prepared to sample much more intensively to avoid lower power problems at the field scale.

Another option which may help to alleviate low power issues somewhat is to bulk samples collected across the whole field site, or a portion of it. This will reduce variability between samples, whilst having less effect on the mean. However this process will lose information about within-field variability and de Campillo et al. (1996) report that bulking can cause systematic bias in organic matter measurements. 


\subsection{Carbon fractions}

Due to the high clay content of the soils at Clapham Park, the majority of carbon was found in the s+c-rSOC fraction, followed by the POM fraction, which was largest close to the soil surface. Compared to a recent analysis on another Bedfordshire clay soil (Upson and Burgess, 2013), the proportion of total sample carbon made up by the rSOC fraction at Clapham Park was between two and three orders of magnitude smaller. The mean proportion of bulk soil organic carbon in the rSOC fraction at Clapham Park (in non-zero samples) was $0.29 \%$ compared to $44.26 \%$. The reasons for this are unclear, but consequently the rSOC results should be considered with caution.

\subsection{Future of soil carbon changes}

It is unclear if the SOC losses from tree establishment on grassland, 14 years after planting, will continue into the future. Huang et al. (2011) noted that the SOC beneath Eucalyptus trees planted on pasture in New Zealand started to recover within ten years of planting. Conversely, in a modelling study based on 100 observations from 16 papers, Poeplau et al. (2011) did not find a recovery in SOC as much as 140 years after tree planting on grassland. In this study, SOC measurements were taken from an adjacent mature grazed woodland (Figure 7) indicate that a recovery of SOC may be possible.

\section{Conclusions}

In agreement with many studies in the literature, we found that tree planting on pasture was associated with a loss of SOC in the uppermost soil layer. Whilst this study did not directly consider the cause of soil carbon losses, two explanations are the loss of perennial grasses in the understorey and an increase in soil respiration due to lower soil water contents.

Fourteen years after planting, the woodland did increase carbon storage as biomass, but about $37 \%$ of the increase in above ground carbon storage was offset by the soil carbon losses at just $0-10 \mathrm{~cm}$. Planting the trees in a silvopastoral system also resulted in a loss of soil carbon in the surface layer, but the greater size of the silvopastoral than the woodland trees, meant that the soil carbon loss represented only $6 \%$ of the increase in above ground storage. A simple analysis suggests that the silvopastoral system was storing about $5 \%$ more carbon than the equivalent separate areas of woodland and pasture. We suggest that the comparison of the systems could also be further enhanced by using the concept of carbon-time.

In this experiment we intensively sampled soil carbon over $0-150 \mathrm{~cm}$ profiles, but we found no statistically significant differences in soil carbon stock below a depth of $10 \mathrm{~cm}$. Power analyses indicated that despite the intensity of sampling, comparison of cumulative SOC values below $0-40 \mathrm{~cm}$ had a greater than $20 \%$ chance of falsely indicating no significant 
change. This low power issue needs to be recognised more widely in the soil science community, as it casts doubt on a large body of previous negative SOC measurements for which power analysis was not completed. Whilst our results indicate that $30 \%$ of SOC stock in the top $150 \mathrm{~cm}$ was stored below $60 \mathrm{~cm}$, there remains a need to establish method to statistically determine changes in carbon without excessive replication.

\section{Acknowledgements}

The woodland and silvopastoral system at Clapham Park site was originally established with support from European Commission, the Forestry Commission, and Bedfordshire County Council. The soil analyses were undertaken with the financial support of the Forestry Commission, Forest Research, and the Scottish Forestry Trust. Writing up of the work was funded through the AGFORWARD (Grant Agreement No 613520) research project co-funded by the European Commission Directorate General for Research \& Innovation. http://www.agforward.eu. Thanks also to Eleanor Chandler, Claire Smith, and particularly Irene Fri as-Hornillos for assistance in completing laboratory and field work, and to Professor Guy Kirk for reading the manuscript prior to submission.

\section{Appendix A}

\section{Appendix A.1. Bulk density}

It was not possible to excavate sample pits in which to take horizontal samples into the soil profile, hence the use of vertical sampling. In a comparison with the more common ring method described by Klute (1986) and taken horizontally into a soil wall, the vertical method underestimated soil bulk density by an average $13 \%$ ( $n=3$ at each of $0-10 \mathrm{~cm}, 10$ $20 \mathrm{~cm}, 20-40 \mathrm{~cm}, 40-60 \mathrm{~cm}$ ). No differences between methods at individual depths were found however; hence this potential underestimation is not an impediment to comparisons between treatments. Furthermore, because the equivalent soil mass method normalises against a reference bulk density of $1.0 \mathrm{~g} \mathrm{~cm}^{-3}$, recalculating SOC values to include an additional $13 \%$ to bulk density measurements did not alter SOC values by more than $0.01 \%$.

\section{Appendix A.2. Total biomass}

The trees at Clapham Park are a native broadleaf mix (Burgess et al., 2000), comprising predominantly oak (Quercus robur L.), ash (Fraxinus excelsior L.), hornbeam (Carpinus betulus L.), small-leaved lime (Tilia cordata Mill.), and field maple (Acer campestre L.). In the absence of measurements of the other species, it has been assumed that the ash trees are representative of the other species. Alternatively one could consider the results as a "what if" scenario, assuming that only ash had been planted.

In order to calculate total biomass $\mathrm{C}$ storage at the Clapham Park site, an allometric equation for total above ground $\mathrm{C}$ content developed from 42 destructive harvests 
(Equation A.1) was applied to each of the $D_{b h}(\mathrm{~mm})$ measurements taken in the woodland ${ }^{1}$ and silvopastoral tree treatments giving above ground $C(\mathrm{~kg})$.

$$
C_{\text {aboveground }}=\alpha D_{b h}{ }^{\beta} C F
$$

Equation A.1

$\alpha=$ regression coefficient $(0.000885)$

$B=$ regression coefficient $(2.13)$

$D_{b h}=$ diameter and breast height $(\mathrm{mm})$

$C F=$ correction factor (1.02) as defined by Baskerville (1972).

Below ground biomass (in tonnes) was calculated by applying a second allometric equation for broadleaved trees (Jenkins et al., 2011, p.48) using Equation A.2

$$
C_{\text {belowground }}=0.483 \alpha D_{b h}{ }^{\beta}
$$

using $\alpha=0.000148, \beta=2.12, D_{\text {bh }}$ in units of $\mathrm{cm}$, and the correction of 0.483 describes the mean carbon for ash tree biomass.

On a per-hectare basis, the silvopastoral blocks were found to contain significantly more biomass $C$ than the woodland treatment (Welch two-sample t-test: $t=12.87, p<0.001, d f=$ 90.90), despite containing $20 \%$ fewer trees. This is due to the fact that trees in the silvopastoral trees tended to have a greater $D_{\text {bh }}$ (though were probably less tall) than trees in the woodland treatment, and consequently greater above and belowground biomass according to the allometric relationships.

Table A.7: Diameter at breast height $\left(D_{b h}\right)$ and estimated biomass carbon for woodland and silvopastoral trees at Clapham Park. Note that silvopasture trees were planted at $2 \mathrm{~m} \times 2 \mathrm{~m}$ spacing, as opposed to $2.5 \mathrm{~m} \times 2.5 \mathrm{~m}$ spacing in the woodland treatment.

\begin{tabular}{llllccccc}
\hline & $\mathrm{D}_{\mathrm{bh}}$ & \multicolumn{2}{c}{$\begin{array}{c}\text { Above ground carbon } \\
\text { biomass } \\
\left(\mathrm{kg} \mathrm{tree}^{-1}\right)\end{array}$} & \multicolumn{2}{c}{$\begin{array}{c}\text { Below ground } \\
\text { carbon biomass } \\
\left(\mathrm{kg} \mathrm{tree}^{-1}\right)\end{array}$} & \multicolumn{2}{c}{$\begin{array}{c}\text { Total carbon biomass } \\
\text { (Mg ha }{ }^{-1} \text { of trees) }\end{array}$} \\
\cline { 3 - 10 } Treatment & $(\mathrm{mm})$ & Mean & SE & Mean & SE & Mean & SE & $n$ \\
\hline Woodland & 92 & 14.09 & 0.65 & 8.35 & 0.38 & 35.90 & 1.64 & 74 \\
Silvopastoral & 121 & 24.98 & 1.17 & 14.78 & 0.69 & 99.41 & 4.65 & 74 \\
\hline
\end{tabular}

\section{References}

Bambrick, A.D., Whalen, J.K., Bradley, R.L., Cogliastro, A., Gordon, A.M., Olivier, A., Thevathasan, N.V., 2010. Spatial heterogeneity of soil organic carbon in tree-based intercropping systems in Quebec and Ontario, Canada. Agroforestry Systems 79 (3), 343-353.

Baskerville, G., 1972. Use of logarithmic regression in the establishment of plant biomass. Canadian Journal of Forest Research 2, 49-53. Benjamini, Y., Hochberg, Y., 1995.

\footnotetext{
${ }^{1}$ Note that only trees planted within areas with a nominal spacing of $2.5 \mathrm{~m}$ were used for the woodland treatment.
} 
Controlling the false discovery rate: a practical and powerful approach to multiple testing. Journal of the Royal Statistical Society 57 (1), 289-300.

Bradley, R., Milne, R., Bell, J., Lilly, A., Jordan, C., Higgins, A., 2005. A soil carbon and land use database for the United Kingdom. Soil Use and Management 21 (4), 363-369.

Broom, D.M., Galindo, F.A., Murgueitio, E. 2013 Sustainable, efficient livestock production with high biodiversity and good welfare for animals. Proceedings of the Royal Society $B$ 280: 20132025.

Burgess, P.J., Graves, A.R., Goodall, G.R., Brierley, E.D.R., 2000. Bedfordshire Farm Woodland Demonstration Project: Final Report to the European Commission.

Burgess, P.J., Incoll, L.D., Corry, D.T., Beaton, A. \& Hart, B.J., 2005. Poplar growth and crop yields within a silvoarable agroforestry system at three lowland sites in England. Agroforestry Systems 63: 157-169.

Burgess, P.J., Reinhard, B.R., Pasturel, P., 2006. Compatible measurements of volumetric soil water content using a neutron probe and Diviner 2000 after field calibration. Soil Use and Management 22, 401-404.

Cranfield University, 2014. The Soils Guide. [Accessed: 23/02/2014] https://www.landis.org.uk/. URL https://www.landis.org.uk/

Davidson, E.E.A., Belk, E., Boone, R.D R., 1998. Soil water content and temperature as independent or confounded factors controlling soil respiration in a temperate mixed hardwood forest. Global change biology 4 (2), 217-227 URL http://doi.wiley.com/10.1046/j.1365-2486.1998.00128.x

de Mendiburu, F., 2014. agricolae: Statistical Procedures for Agricultural Research. R package version 1.2-1. URL http://CRAN.R-project.org/package=agricolae

del Campillo, M.C., van der Zee, S.E.A.T.M., van Riemsdijk, W.H., 1996. Systematic bias in measuring intensities by selective extraction of bulked samples. Communications in Soil Science and Plant Analysis 27 (5-8), 1829-1841.

Ellert, B., Bettany, J., 1995. Calculation of organic matter and nutrients stored in soils under contrasting management regimes. Canadian Journal of Soil Science 75 (4), 529-538.

Forestry Commission, 2013. Woodland Carbon Code - About the Code - Guidance - 3.4 Project Carbon Sequestration. URL http://www.forestry.gov.uk/forestry/INFD8JUE9T\#soil

Graves, A.R., Burgess, P.J., Palma, J.H.N., Herzog, F., Moreno, G., Bertomeu, M., Dupraz, C., Liagre, F., Keesman, K., van der Werf, W. Koeffeman de Nooy, A., van den Briel, J.P. 2007. Development and application of bio-economic modelling to compare silvoarable, arable and forestry systems in three European countries. Ecological Engineering 29: 434-449.

Guo, L. B., Gifford, R. M., 2002. Soil carbon stocks and land use change: a meta analysis. Global Change Biology 8, 345-360.

Harper, R. J., Tibbett, M., 2013. The hidden organic carbon in deep mineral soils. Plant and Soil 368 (1-2), 641-648. 
Hoenig, J.M., Heisey, D.M., 2001. The Abuse of Power: The Pervasive Fallacy of Power Calculations for Data Analysis. The American Statistician 55 (1), 1-6.

Hoogmoed, M., Cunningham, S., Thomson, J., Baker, P., Beringer, J., Cavagnaro, T., 2012. Does afforestation of pastures increase sequestration of soil carbon in Mediterranean climates? Agriculture, Ecosystems \& Environment 159, 176-183.

Huang, Z., Davis, M.R., Condron, L.M., Clinton, P.W., 2011. Soil carbon pools, plant biomarkers and mean carbon residence time after afforestation of grassland with three tree species. Soil Biology and Biochemistry 43 (6), 1341-1349.

Hungate, B., Jackson, R., Field, C., Chapin III, F., 1995. Detecting changes in soil carbon in CO2 enrichment experiments. Plant and Soil 187, 135-145.

IPCC, 2000. Land Use, Land-Use Change and Forestry. Cambridge University Press, Cambridge, England.

Jackson, R.B., Mooney, H.A., Schulze, E.D., 1997. A global budget for fine root biomass, surface area, and nutrient contents. Proceedings of the National Academy of Sciences of the United States of America 94 (14), 7362-6.

Jenkins, T., Mackie, E., Matthews, R., Miller, G., Randle, T., White, M., 2011. FC Woodland Carbon Code : Carbon Assessment Protocol. Tech. rep.

Jose, S., 2009. Agroforestry for ecosystem services and environmental benefits: an overview. Agroforestry Systems 76 (1), 1-10.

Kirschbaum, M.U., Guo, L.B., Gifford, R.M., 2008. Why does rainfall affect the trend in soil carbon after converting pastures to forests? Forest Ecology and Management 255 (7), 2990-3000.

Klute, A., 1986. Methods of Soil Analysis: Part 1 - Physical and Mineralogical Methods, 2nd Edition. American Society of Agronomy, Wisconsin.

Kravchenko, A.N., Robertson, G.P., 2011. Whole-Profile Soil Carbon Stocks: The Danger of Assuming Too Much from Analyses of Too Little. Soil Science Society of America Journal 75 (1), 235-240.

Laganiere, J., Angers, D.A., Pare, D., 2010. Carbon accumulation in agricultural soils after afforestation: a meta-analysis. Global Change Biology 16 (1), 439-453.

Landmark Information Group, 2004. Ordnance Survey County Series 1st Edition [TIFF geospatial data], Scale 1:2500, Bedfordshire, 1883. URL http://edina.ac.uk/digimap

Leys, C., Ley, C., Klein, O., Bernard, P., Licata, L., 2013. Detecting outliers: Do not use standard deviation around the mean, use absolute deviation around the median. Journal of Experimental Social Psychology 49 (4), 764-766. URL http://dx.doi.org/10.1016/j.jesp.2013.03.013

Montagnini, F., Nair, P.K.R., 2004. Carbon sequestration: an underexploited environmental benefit of agroforestry systems. Agroforestry Systems 61, 281-295.

Mosquera-losada, R., Freese, D., Rigueiro-Rodriguez, A., 2011. Carbon Sequestration in European Agroforestry Systems. In: Kumar, B. M., Nair, P. K. R. (Eds.), Carbon Sequestration Potential of Agroforestry Systems, 1st Edition. Springer, pp. 43-59. 
NSRI, 2012. Full Soils Site Report for location 504812E, 252514N, 1km x 1km,. Tech. Rep. July, National Soil Resources Institute, Cranfield University. URL https://www.landis.org.uk/sitereporter/

Page, W., 1912. Parishes - Clapham. In: A History of the County of Bedford. British History Online, pp. 128-132. URL http://british-history.ac.uk/report.aspx?compid=42397

Paul, K., Polglase, P., 2002. Change in soil carbon following afforestation. Forest Ecology and Management 168, 241-257.

Paul, K., Polglase, P., Richards, G., 2003. Predicted change in soil carbon following afforestation or reforestation, and analysis of controlling factors by linking a $C$ accounting model (CAMFor) to models of forest growth (3PG), litter decomposition (GENDEC) and soil C turnover (RothC). Forest Ecology and Management 177 (1-3), 485501.

Poeplau, C., Don, A., Vesterdal, L., Leifeld, J., Van Wesemael, B., Schumacher, J., Gensior, A., 2011. Temporal dynamics of soil organic carbon after land-use change in the temperate zone - carbon response functionsas a model approach. Global Change Biology 17 (7), 2415-2427.

Post, W.M., Kwon, K.C., 2000. Soil carbon sequestration and land-use change: processes and potential. Global Change Biology 6 (3), 317-327.

R Development Core Team, 2015. R: A language and environment for statistical computing. URL http://www.r-project.org

Rasse, D.P., Rumpel, C., Dignac, M.-F., 2005. Is soil carbon mostly root carbon? Mechanisms for a specific stabilisation. Plant and Soil 269 (1-2), 341-356.

Shi, S., Zhang, W., Zhang, P., Yu, Y., Ding, F., 2013. A synthesis of change in deep soil organic carbon stores with afforestation of agricultural soils. Forest Ecology and Management 296, 53-63.

Sibbald, A., Eason, W., McAdam, J., Hislop, A., 2001. The establishment phase of a silvopastoral national network experiment in the UK. Agroforestry Systems 39, 39-53.

Stockmann, U., Adams, M.A., Crawford, J.W., Field, D.J., Henakaarchchi, N., Jenkins, M., Minasny, B., McBratney, A.B., Courcelles, V.D.R.D., Singh, K., Wheeler, I., Abbott, L., Angers, D.A., Baldock, J., Bird, M., Brookes, P.C., Chenu, C., Jastrow, J.D., Lal, R., Lehmann, J., O'Donnell, A.G., Parton, W.J., Whitehead, D., Zimmermann, M., 2013. The knowns, known unknowns and unknowns of sequestration of soil organic carbon. Agriculture, Ecosystems \& Environment 164, 80-99.

Thomas, L., 1997. Retrospective power analysis. Conservation Biology 11 (1), 276-280.

Udawatta, R.P., Garrett, H.E., Kallenbach R. 2011. Agroforestry buffers for nonpoint source pollution reductions from agricultural watersheds. Journal of Environmental Quality 40: 800-806.

UNEP, 2011. Bridging the Emissions Gap. Tech. rep., United Nations Environment Programme (UNEP).

Upson, M.A., Burgess, P.J., 2013. Soil organic carbon and root distribution in a temperate arable agroforestry system. Plant and Soil 373 (1-2), 43-58. 
West, V., 2011. Soil carbon in the Woodland Carbon Code. Tech. rep., Forestry Commission, Edinburgh. URL http://goo.gl/m83crZ

Wickham, H., Francois, R., 2015. dplyr: a grammar of data manipulation. R package version 0.4.1. URL http://CRAN.R-project.org/package=dplyr

Zimmermann, M., Leifeld, J., Schmidt, M. W. I., Smith, P., Fuhrer, J., 2007. Measured soil organic matter fractions can be related to pools in the RothC model. European Journal of Soil Science 58 (3), 658-667. 
